\title{
Overcoming the limits of institutional reform in Uganda
}

Matt Andrews/Lawrence Bategeka

CID Working Paper No. 269

October 2013

(C) Copyright 2013 Andrews, Matt; Bategeka, Lawrence; and the President and Fellows of Harvard College

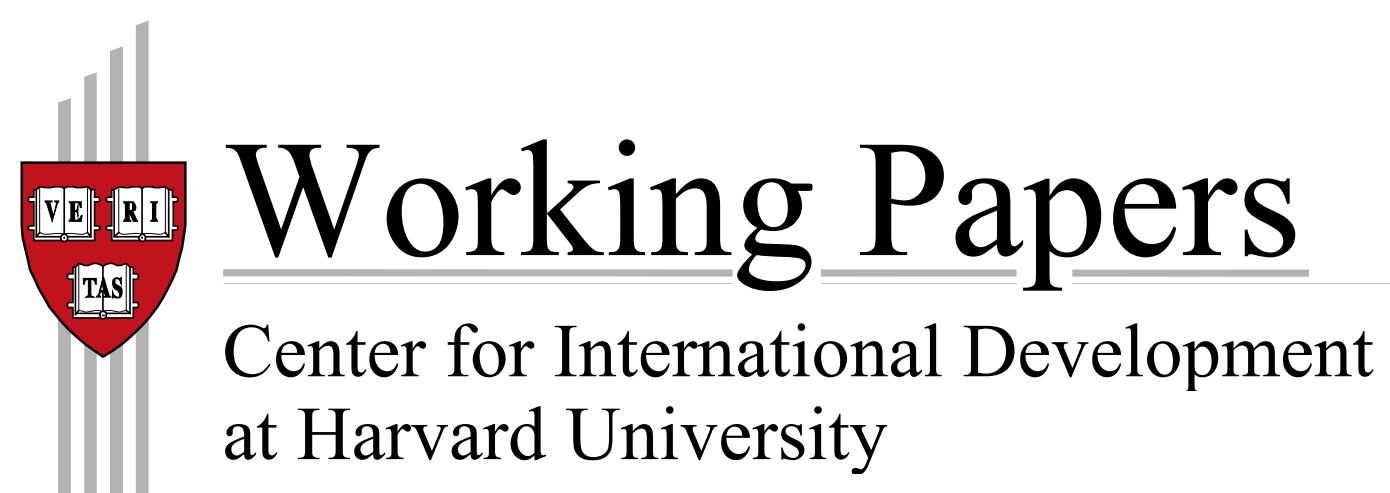




\title{
WIDER Working Paper No. 2013/111
}

\section{Overcoming the limits of institutional reform in Uganda}

\section{Matt Andrews ${ }^{1}$ and Lawrence Bategeka ${ }^{2}$}

October 2013

\begin{abstract}
This paper begins by noting that Uganda has been a public sector reform leader in Africa. It has pursued reforms actively and consistently for three decades now, and has produced many laws, processes and structures that are 'best in class' in Africa (and beyond). The problem is that many of the reforms have been limited to these kinds of gains - producing new institutional forms that function poorly and yield limited impacts. Various kinds of data showed - in various areas (civil service and public administration, public financial management, revenue management, procurement, and anti-corruption) - that laws are often not being implemented, processes are being poorly executed, and there is insufficient follow-up to make sure that new mechanisms work as intended. The paper suggests that government should reframe its reform agenda to address these limitations and close the gaps between what Uganda's system looks like and how it functions.

The proposed approach to doing reform in the future is called problem-driven iterative adaptation (PDIA) and builds on past reform activity (rather than proposing an entirely new set of solutions). PDIA will require Ugandans to work together and own their reform processes more actively than ever, coming to terms with the problems they face and working iteratively — in broad groups - to find and fit local solutions to these problems.
\end{abstract}

Keywords: development, Uganda, reform, growth, governance, Africa

JEL classification: H11, O10, O19

Copyright (c) UNU-WIDER 2013

${ }^{1}$ Harvard Kennedy School, Cambridge, MA. Matt_Andrews@hks.harvard.edu; ${ }^{2}$ Economic Policy Research Center, Kampala

This working paper has been prepared within the UNU-WIDER project 'Building State Capability through Problem-Driven Iterative Adaptation (PDIA)' directed by Lant Pritchett and Matt Andrews, which is a component of the larger UNU-WIDER programme 'Foreign Aid: Research and Communication (ReCom)'

UNU-WIDER gratefully acknowledges specific programme contributions from the governments of Denmark (Ministry of Foreign Affairs, Danida) and Sweden (Swedish International Development Cooperation Agency-Sida) for ReCom. UNU-WIDER also gratefully acknowledges core financial support to its work programme from the governments of Denmark, Finland, Sweden, and the United Kingdom 


\section{Acknowledgements}

This is a project funded by UK Aid, UK Department for International Development (DFID) for the benefit of developing countries. However, the views expressed and information contained in it are not necessarily those of or endorsed by DFID, which can accept no responsibility for such views or information or for any reliance placed on them.

Acronyms

CSRP civil service reform programme

IFMS financial management information system

IPPS integrated personnel and payroll system

NRM National Resistance Movement

PDIA problem-driven iterative adaptation

ITD International Tax Dialogue

OBI open budget index

PEFA public expenditure and financial accountability

PETS public expenditure tracking survey

IFMIS integrated financial management system

PFM public financial management

PSRRC Public Service Review and Reorganization Commission

MTEF medium-term expenditure framework

URA Uganda Revenue Authority

The World Institute for Development Economics Research (WIDER) was established by the United Nations University (UNU) as its first research and training centre and started work in Helsinki, Finland in 1985. The Institute undertakes applied research and policy analysis on structural changes affecting the developing and transitional economies, provides a forum for the advocacy of policies leading to robust, equitable and environmentally sustainable growth, and promotes capacity strengthening and training in the field of economic and social policy making. Work is carried out by staff researchers and visiting scholars in Helsinki and through networks of collaborating scholars and institutions around the world. www.wider.unu.edu publications@wider.unu.edu

UNU World Institute for Development Economics Research (UNU-WIDER)

Katajanokanlaituri 6 B, 00160 Helsinki, Finland

Typescript prepared by Liisa Roponen at UNU-WIDER.

The views expressed in this publication are those of the author(s). Publication does not imply endorsement by the Institute or the United Nations University, nor by the programme/project sponsors, of any of the views expressed. 
On the one hand ... there is clear evidence - that government is more competent ... the legislation is better, the monitoring and evaluation systems are better, the financial management is much more proficient, public procurement and disposal of assets is better ... but on the negative side is the issue of impacts. What is all this doing in terms of changing the lives of the people for the better? That is where the problem is.

\section{John Kiyaga-Nsubuga, Director General, Uganda Management Institute1}

Another major problem facing Uganda today is the problem of 'let's pass new laws' ... Laws are being passed every single day yet the ones present are neither effective nor implementable.

\section{Oscar Otindo, Journalist 2}

\section{Introduction}

Uganda has been a public sector reform leader in Africa. It was one of the earliest countries to initiate reforms on the continent in the 1980s and was an early adopter of many interventions that are now ubiquitous on the continent. These include independent revenue agencies, medium-term expenditure frameworks, public expenditure tracking surveys, and results oriented management mechanisms. A number of the solutions introduced in these reforms are respected across the continent because they have yielded best-in-class new laws, organizational arrangements and operational mechanisms. The problem is that many of the reforms have been limited to these kinds of gains - producing new institutional forms that function poorly and yield limited impacts. New anticorruption laws are largely unimplemented, for instance, which means that corruption continues to be a major problem; impressive looking budgets are poorly executed, which means that public expenditure results are still constrained; the revenue agency collects less revenue than possible, which means that the government lacks resources to independently provide the services and infrastructure needed to develop Uganda; and more. This paper explores the limits of institutional reform in Uganda and suggests an approach that could help the government could pursue less-limited reforms in future.

The paper has four main sections. Following the introduction, the second section provides a brief historical narrative of Uganda's public sector reforms since the mid-1980s. It focuses on five dominant areas of reform: in the civil service and public administration, public financial management, revenue management, procurement, and anti-corruption. ${ }^{3}$ In all areas one can see that the government has pursued a full reform agenda with ample support from international organizations like the World Bank and DFID. The narrative also shows that

1 Page 8 of the interview transcript for Princeton University's Innovations for Successful Societies (ISS) programme, conducted by Andrew Schalkwyk on 1 December 2008. Available from www.princeton.edu/successfulsocieties.

2 Article written by Otindo (2012).

3 This analysis does not cover all of the key areas in which reform has transpired, but the themes that are developed resonate with studies on important intervention like decentralization which also find major gaps between the intention of reform and its implementation and achievement. See, for instance, Bashaasha et al. (2011). 
many best practice institutional mechanisms have been created in the last thirty years, often through projects considered successful by government and donors. A third section discusses results of these interventions. It does so by referencing recent evaluations and assessments available in each of the five areas. These include the public expenditure and financial accountability (PEFA) data, open budget index (OBI), and Global Integrity statistics. These sources all show that Uganda's reforms have been very successful in creating new institutional forms but have been quite unsuccessful in improving actual government functionality. This leaves a string of reform limits and gaps that are currently undermining the impact of government in Uganda. A fourth section suggests that government should reframe its reform agenda moving ahead, addressing real problems of dysfunction directly instead of adopting hopeful best practice solutions. It argues that the gaps between form and function identified in this paper offer excellent entry points for this new kind of reform agenda.

The paper intends to contribute to the institutional reform discussion that is obviously ongoing in Uganda and reflected in the three recent quotes shown above. On the face of it, the analysis might appear overly critical of past reforms. Those who have toiled in these reforms may even take umbrage at the narrative of reforms that have been limited to gains in form with little improvement in functionality. This perspective will be unfortunate, given that the narrative should not be read as an overly negative one but should instead be considered as both a commentary of what has worked and what the next challenges are in Uganda. The fact that reforms have yielded gains in terms of new forms indicates that Uganda's reformers have the capability to make change happen. The fact that reforms have been limited shows that Uganda's reformers need to think about how it makes change happen in a more tangible way, as the next step of the country's reform journey. This kind of narrative is not new or unwelcome in Uganda according to John Kiyaga-Nsubuga, the Director General of the Uganda Management Institute, who commented in 2008 that, 4

I have attended a number of high-level discussions where [reformers] are questioning everything themselves ... [asking] 'We have done this, but has it produced - or how far have we gone to achieve that?' So, they have already recognized their limitations and are in a stage of redesigning their programmes...

The paper also intends to contribute to the literature on institutional reform in developing countries beyond Uganda. This literature is often taken up with papers that discuss the merits and details of specific kinds of interventions - like decentralization or democratic governance or multi-year budgeting. These interventions are seldom seen as part of broad reform agendas (that spread across time and different areas of engagement and government) and they are often poorly evaluated, leading to many apparently 'successful' reforms that do not yield more functional governments. This paper presents an approach to investigating and evaluating reforms that takes a broad perspective - through the historical narrative - and ensures a structured empirical view - using multiple indicators and an 'institutional limits and gap analysis' to assess reform progress in a systematic and analytical way that should help focus discussion and strategies in future. 5

\footnotetext{
4 ISS (2008).

5 The approach builds on Andrews (2013) and Andrews et al. (2013).
} 


\section{A brief retrospective of Uganda's public sector reforms 6}

In 1986 when President Museveni's National Resistance Movement (NRM) ascended to power, his government inherited a largely dysfunctional public service. The maladies were too numerous to mention: government bureaucracy and red-tape had become major bottlenecks in service delivery; the public service was bloated with excessive manpower; motivation in the public service - especially of teachers and health workers - was low; there was no strategic direction for government to follow; the state was in fiscal turmoil, with uncertain spending patterns and large debt burdens; there was limited revenue to cover debt repayments or to fund needed public sector engagements; corruption was considered a major problem.

Faced with these challenges, the NRM government promised Uganda's citizens a fundamental change in the management of public affairs, adopting a ten-point reform programme soon after taking office. This was followed by the adoption of an economic recovery package (which sought to liberalize and stabilize the economy) in 1987, the establishment of the Public Service Review and Reorganization Commission (PSRRC) in 1988, the adoption of this Commission's report as a blueprint for reform in 1989, and the launch of a civil service reform programme (CSRP) in the early 1990s. These steps were among the first in what Figure 1 shows has been a constant and busy process of reform over the past thirty years.

The timeline in the top half of Figure 1 shows some of the key milestones in public service, decentralization and anticorruption reforms in Uganda since 1986. The bottom half shows key milestones in public financial management and revenue management reforms. One can see that all of these reform types have seen active engagement since the early 1990s when the Uganda Revenue Authority (URA) was created, a new constitution was introduced, pay reforms were initiated, the civil service was rationalized and streamlined, and budget reforms were adopted. It should be noted that many of the reforms attempted during this time have had a cutting edge dimension to them as well: Uganda were one of the first countries to adopt a semi-autonomous revenue agency in Africa, for instance, and their efforts to introduce medium-term budgeting in the early 1990s predated efforts to do so in other African countries (including South Africa, where medium-term expenditure frameworks were only introduced in the late 1990s).

The mid to late 1990s saw a variety of initiatives aimed at streamlining the civil service, formalizing the public financial management system, and focusing the public administration. This period laid the foundation for a series of interventions introducing decentralization and emphasizing basic service provision (especially universal primary education). The push for aggressive public sector service delivery was guided by the Poverty Eradication Action Plan (PEAP), which was the first of a number of plans Uganda's government has adopted in the past twenty years. The PEAP saw a push to deliver various services by local governments, which was a common reform in Africa at the time (Andrews 2003a). The major decentralization mandate emerged from the 1995 Constitution, the Decentralization Statute No. 15 of 1995, and the Local Government Act of 1997.

6 This section draws on descriptions of Uganda's reform experience by (among others) Karakire (undated), Olum (2003), Williamson (2003), Robinson (2006), Kyarimpa (2009), and Bategeka (2013). 
Figure1. A simplified timeline of Uganda's public sector reforms, 1986 to 2012

Source: Authors' analysis.

The government revived the civil service reforms once again in the late 1990s as well, with the public service reform programme, a new commitment to pay reform, and efforts to introduce performance management mechanisms. Once again, these efforts were at the vanguard of reforms in Africa, where few countries were seriously considering introducing a 
results focus in government (Andrews 2005). Uganda's expenditure tracking efforts were also novel at this time, and have since become a 'best practice' across Africa.

The 2000s saw a flurry of new laws passed as part of the continuing public sector reform initiatives. These included laws aimed at further improving the public financial management system. The Budget Act and Public Financial Accountability Act stood out as impressive legislative interventions and the Public Procurement and Disposal of Public Assets Act remains one of the most advanced procurement laws in the world. A host of new laws and regulations were also introduced to combat corruption. These included the Inspectorate of Government Act, the Leadership Code Act and the Anti-Corruption Act. Various organizational adjustments were made in concert with these new laws, leading to the creation of new bodies to provide financial, procurement and other oversight mechanisms in the country. These bodies create and monitor rules of the game, conduct audits, and oversee the implementation of laws.

Public financial management (PFM) reforms continued apace in the 2000s as well, financed through projects like the financial management and accountability programme (FINMAP). New laws and regulations were created to guide PFM in local and national governments and oversight bodies were created (like the Budget Monitoring and Accountability Unit, BMAU). Furthermore, efforts were made to introduce IT-based systems through which PFM practices would be made more formal. Pilots were launched to adopt an integrated financial management information system (IFMS) as early as 2003/04 and an integrated personnel and payroll system (IPPS) was introduced in 2008. The IPPS went 'live' in 2013 as the basis for paying all salaries. Its implementation led to calls for new budget laws which are currently being considered, as is new legislation in areas like anti-corruption and civil service. The latter laws are considered necessary as Uganda continues to struggle with high levels of corruption, attempts to adopt performance-based contracts, focuses on achieving the goals set in various national plans and strategies, addresses corruption, and promotes economic growth.

\section{Successful change in forms, but limited improvement in functionality}

The discussion above only gives a partial perspective on Uganda's public sector reform experience over the past quarter century. The main intention is to show how much activity this experience has involved. One cannot look at Figure 1 without recognizing that Uganda has done a lot in this area. This is also the impression one gets when examining the history of project engagements with the World Bank (just one development partner). Since 1990, Uganda has partnered with the Bank on at least 20 projects focused on administrative and civil service reform, 14 projects addressing public financial management reform, 15 aimed to foster decentralization, and seven targeting improvements in tax policy and administration. 7 Over two-thirds of the World Bank projects that have been evaluated were considered satisfactory as well, suggesting they met expectations. But where have these and other projects and reform interventions left Uganda today?

This section argues that the results are mixed: Uganda's government looks better after the reforms but there are many reform limits that undermine government's post-reform functionality and impact.

7 This is based on the authors' calculations, given data in the World Bank project database. 


\subsection{Uganda's government looks better after all the reforms ${ }^{8}$}

Table 1 summarizes some of the gains one can readily identify when studying evaluations of Uganda's reforms. The left-most column starts by giving some perspective on gains and achievements in the civil service and public administration domain, for instance. It draws on evaluations and assessments that are extremely positive about the way reforms led to a streamlined state in the 1990s. In this period, the civil service was reduced from 320,000 on the payroll to about 160,000 in 1998 (numbers are approximate because it is difficult to ascertain exact figures due to changes in employee classification and such). 9 This was a direct and positive gain given that Uganda faced a problematic bloated bureaucracy in 1988, where employment in the public sector accounted for about two-thirds of all formal sector jobs - a fiscally unsustainable position. In contrast, by 1998 the public sector accounted for only about a third of all formal sector jobs - a more balanced reality. Furthermore, payroll and establishment controls were put in place and benefits monetized by the late 1990s, which led to improved public sector wages in this period.

Additional civil service and public administration reform gains in the 2000s centred on the government's introduction of 'best practice' performance management mechanisms. These emerged in various guises since the late 1990s and involve output and outcome based budgeting, performance targeting in national planning mechanisms (like the 2010 National Development Plan), and civil service performance contracts. Altogether, the mechanisms allow one to see exactly what government intends to do and ties performance targets to conditions of employment for most senior civil servants. The coverage of these reforms is remarkable, given that at the end of 2010 all senior government officials, 92 per cent of head teachers and all hospital directors were on performance contracts that allowed this kind of performance orientation.

Public financial management (PFM) reforms have also yielded major gains and achievements. In particular, they have resulted in the adoption of new laws, management systems, and administrative processes. These were being established progressively from the early 1990s and include the medium-term expenditure framework (MTEF), public expenditure tracking surveys (PETS), outcome/output oriented budgeting, and the new IFMIS system. The impressive nature of these kinds of mechanisms is reflected in the country's strong performance on globally recognized measures of PFM system quality. Uganda's laws and formal processes satisfy 70 per cent of the requirements in the PEFA measure used by most development partners (see de jure scores in Appendix Table 1). 10 This suggests that the

8 Most references are provided in association with Table 1, so as to minimize the need for footnotes.

9 The number of line ministries was capped at 21 in the 1995 Constitution and the number of cabinet ministers was also held at a relatively low level (of 40).

10 This statistic is based on the authors' analysis of the PEFA data using methods developed in Andrews (2011). This method sees one identifying the dimensions of the PEFA analysis that relate to de jure performance (where a B is possible if a government simply adopts a new law or process, regardless of the implementation or use of such law or system or process). Uganda scores 2.8 out of 4 on average when looking at such dimensions. 


\begin{tabular}{|c|c|c|}
\hline . & 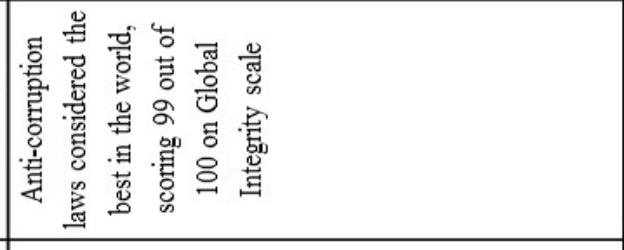 & \multirow{3}{*}{ 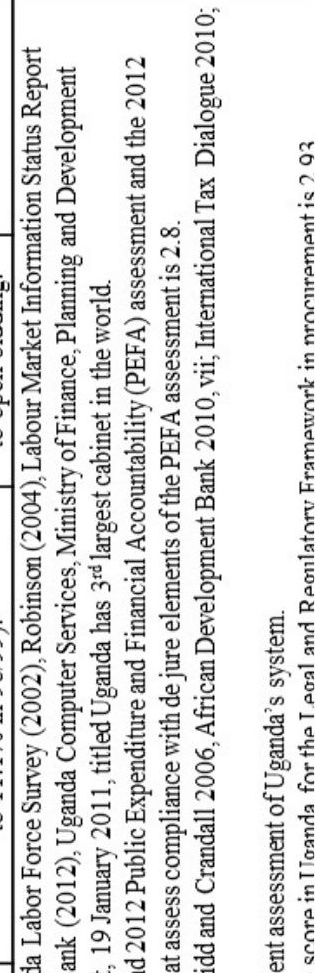 } \\
\hline & 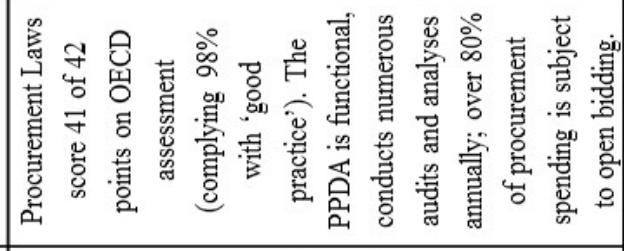 & \\
\hline 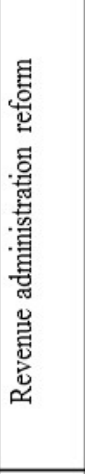 & 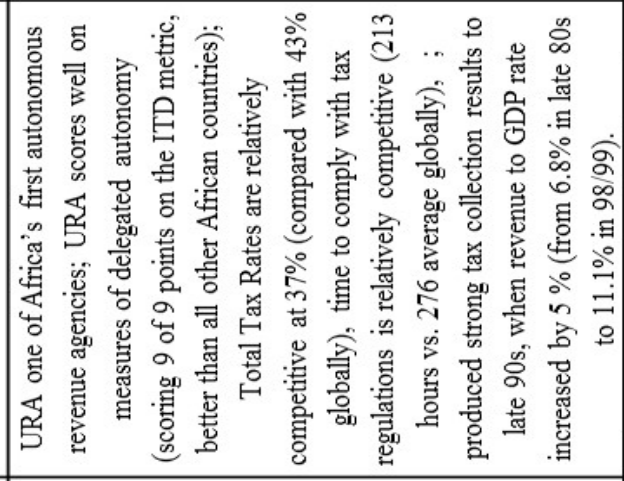 & \\
\hline \multirow{2}{*}{ 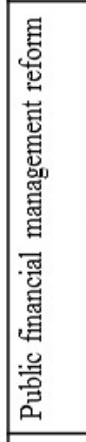 } & 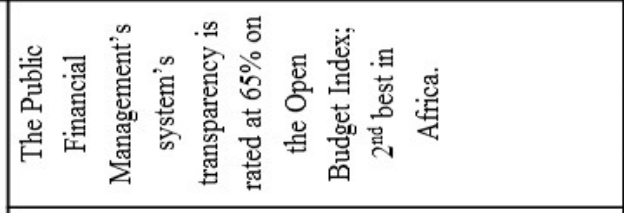 & \multirow{5}{*}{ 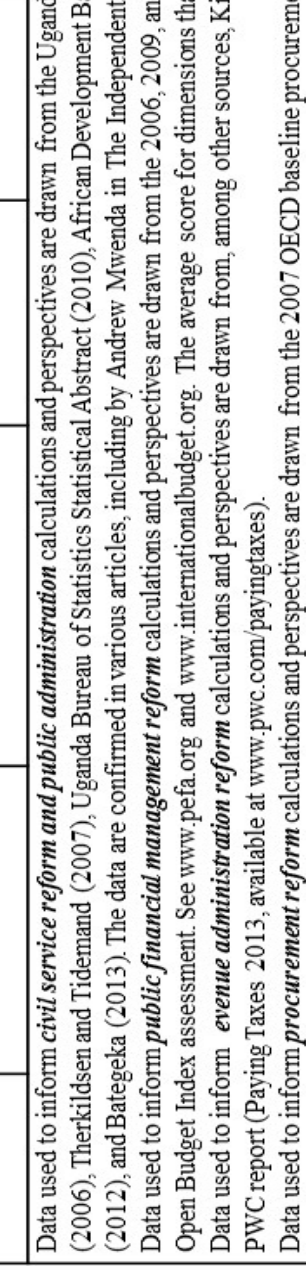 } \\
\hline & 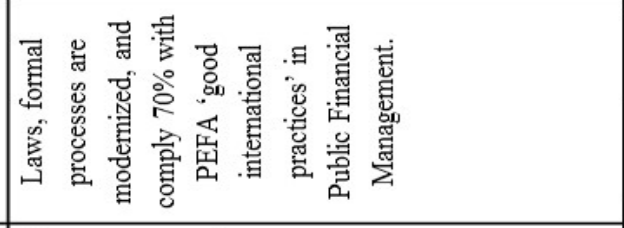 & \\
\hline 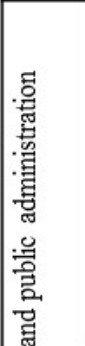 & 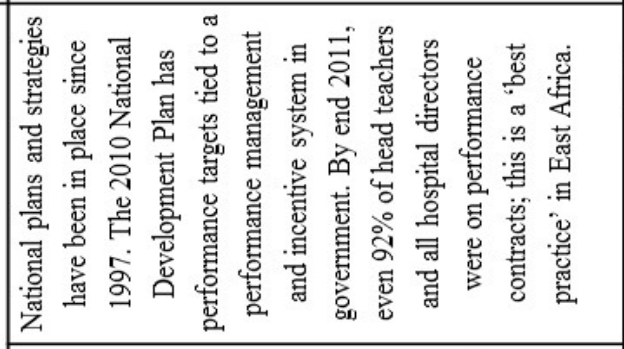 & \\
\hline & 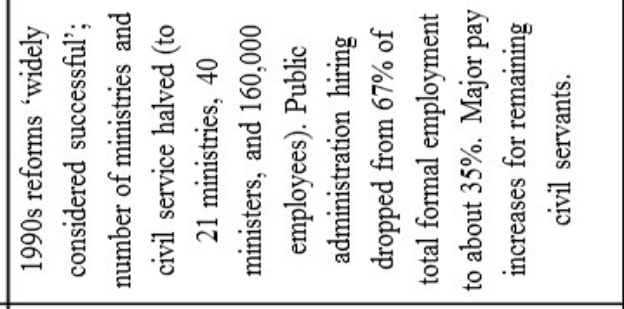 & \\
\hline & 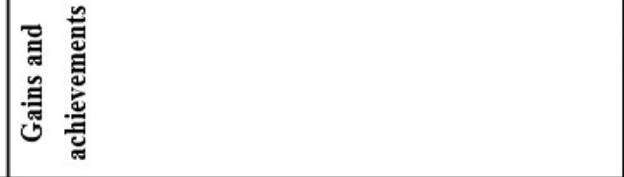 & \\
\hline
\end{tabular}


legal and formal process quality of Uganda's system is 70 per cent compliant with what experts consider 'good international practice.' The country registers a similar score (65 per cent) on the 2012 open budget index (OBI), which assesses the degree of PFM system transparency (see also Appendix Table 1). This score was higher than all other east African countries. Kenya scored 49 per cent, which is considered 'moderate'. Uganda's score fell into the 'substantial transparency' category of countries scoring between 61 and 80 per cent (which put it at the same level as various OECD countries). 11

Reform gains are also reflected in the area of revenue administration, especially in the form of the Uganda Revenue Authority (URA). Created in the early 1990s, the URA ramped revenue collections up from about 7 per cent of gross domestic product (GDP) (in the late 1980s) to about 11 per cent of GDP in 1998 (AfDB 2010: vii; Therkildsen 2004; Kidd and Crandall 2006). This was one of the most impressive increases in revenue generation in the world at the time and addressed a key problem experienced by the Ugandan government - of low resource mobilization and high dependence on outside financing. The government was considered 'a trail blazer among the countries of the region [given the act of] establishing an autonomous revenue agency' (AfDB 2010: 6). The URA has continued to impress, with a high formal level of autonomy and large scope of activities (meaning it has authority to engage in revenue policy and administrative decisions regarding many different types of revenue). It scores 9 of 9 points for the International Tax Dialogue (ITD) assessment of revenue agency autonomy, and scores 7 of 9 when looking at the areas over which it exercises policy and administrative influence (exceeded only by Tanzania and Mauritius, given limits over the URA's influence on property tax and social security) (ITD 2010; Kidd and Crandall 2006: 89). It also ensures a system that performs well on global indicators measuring the ease of paying taxes. A 2012 analysis showed, for instance, that the URA has managed to keep tax rates low (with total tax rates of 37 per cent, compared with a global average of 43 per cent) and has minimized the time burden associated with paying taxes (which is at 213 hours, compared with the average of 276 hours globally). This model of a highly autonomous tax agency, with relatively low costs of operation, has been studied and lauded continent-wide.

The same could be said of the legal and organizational infrastructure created for public procurement over the past decade. Uganda has developed a thorough legal and regulative framework for procurement, including at the local level, through the 1995 Constitution, 1997 Local Government Act (amended in 2006), 2003 Public Procurement and Disposal of Public Assets (PPDA) Act, 2006 Local Government PPDA Regulations, and 2008 Local Government PPDA Guidelines (Basheka 2008). These (and other) interventions have led to a best practice deconcentrated model in the country, where local governments and ministries are responsible for doing procurement planning and managing procurement transactions; with a central agency (the PPDA) creating rules and providing monitoring and oversight. The promising nature of this new procurement system - and the gains already achieved through such - is described in recent comments from Anja Kramer (of the German aid agency KfW) and Howard Centenary (of the World Bank). In discussing the PPDA's 2012 Public Procurement Symposium and Exhibition, they note that (New Vision 2012):

... resulting from the enactment of the Public Procurement and Disposal of Public Assets Act, 2003, procurement is now decentralized to the spending agencies and the Public Procurement and Disposal of Assets Authority

11 Rwanda scored 8, Tanzania scored 47. Taken from article in the Business Daily, 12 February 2013. 
(PPDA) is now well established regulator ... These reforms have emphasized transparency in procurement ... [and] over 80 per cent of government expenditure through procurement is subject to open bidding with these contracts advertised in public media... Establishment of a procurement grievance handling mechanism is another achievement... PPDA has improved its monitoring system and has to date conducted 329 audits in 221 procuring agencies since its establishment in $2003 \ldots$

The reforms in procurement have yielded strong scores for Uganda on various donor-driven assessments of the system. For instance, Uganda's legal and regulatory framework scored 41 of 42 points in the 2007 OECD procurement assessment (averaging 2.93 out of 3) (see Appendix Table 2). This suggests that the laws in place complied about 98 per cent with international 'good practice' in 2007, which was an improvement from the score in 2005 (where the average was 2.5 out of 3). These data are corroborated by Global Integrity's assessments of the procurement system which give full marks (100 of 100) for all of the following (see more in Appendix Table 3):

- In law, regulations address conflicts of interest for public procurement officials.

_ In law, there is mandatory professional training for public procurement officials.

_ In law, a mechanism monitors assets, incomes spending habits of ... officials.

- In law, major procurements require competitive bidding.

- In law, strict formal requirements limit the extent of sole sourcing.

- In law, unsuccessful bidders can instigate an official review of ... decisions.

- In law, unsuccessful bidders can challenge procurement decisions in a court of law.

- In law, companies guilty of major violations of procurement regulations (i.e., bribery) are prohibited from participating in future procurement bids.

- In law, citizens can access public procurement regulations.

- In law, government is required to publicly announce results of decisions.

Uganda's procurement reforms have always been tied to the larger goal of anti-corruption, given a legacy of graft in Uganda's public purchasing processes. There are other dimensions of the anti-corruption reforms as well, however, which have often built on the 1970 Prevention of Corruption Act. This was amended in 1988 as one of the new government's first public sector reform interventions; to prevent people accused of corruption from disposing freely on money in their bank accounts. The 1995 Constitution directly addressed the corruption issue as well, stipulating that, 'all lawful measures shall be taken to expose, combat and eradicate corruption and abuse or misuse of power by those holding political and other public offices'.12 Following this, the government adopted a range of extra legal and regulatory mechanisms to tackle bribery, patronage, and other forms of corruption. Between 2000 and 2005 the government introduced '.. further legal instruments for fighting corruption includ[ing] the Inspectorate of Government Act, the Government Finance Regulations, the Public Service Act, the Public Service Standing Orders, the Local Government Act and the Leadership Code Act' (Ittner 2009: 82). It continued introducing

12 Constitution of the Republic of Uganda, Article XXVI. 
such institutional structures after 2005, including a Code of Conduct and Ethics, AntiCorruption Act, Whistleblowers Protection Act, and Anti-Money Laundering Bill.

In reflecting on these kinds of interventions in 2011, Global Integrity gave Uganda 98 points out of 100 for the quality of its legal framework. This was higher than any other country in the world. The United States, for instance, scored 90. Kenya scored 84. Uganda registered full marks on 128 of 135 questions that asked about the nature of laws considered important for establishing an accountable government capable of addressing corruption problems. This equates with having full compliance with legal requirements in 95 per cent of the areas analysed. The United States only registered 90 per cent on the same measure, and countries like Kenya and Ghana were further behind on 84 per cent and 79 per cent, respectively (see Appendix Table 4). This strong performance on legal compliance ensured that Uganda got a score of 72 out of 100 for the overall strength of its 'integrity system', which is higher than most other comparator countries (Kenya scored 68 and Ghana 67). This performance once again reflects positively on the gains and achievements of the past three decades of reforms. On paper, at least, Uganda looks like it has an impressive government that should be able to function effectively.

\subsection{Uganda's government is not as functional as it now looks}

Unfortunately, Uganda's government is not as good as it looks. In practice, the reforms in many areas have actually been limited to impressive appearance and do not yield the kind of action and effectiveness needed for a developing country with major problems getting basic services delivered or addressing significant poverty challenges or socioeconomic deficiencies. Table 2 shows the limits and gaps of reforms in the five areas explored above.

Civil service and public administration reform limits began to manifest in the late 1990s, when government employment started expanding (even after the 1990s cuts). Various policy decisions (like decentralization and universal primary education) led to hiring pressure (in local governments and schools, for instance) and contributed to a major growth in the number of government employees. 13 Precise data are difficult to come by, given the many different conditions of employment for public servants, but various sources suggest that the government now employs between 290 and 330 thousand people-double the amount they had in place in the late 1990s.

The growth in government size would not be a worry if Uganda had money to finance its public employment in a sustainable and controlled manner and if results of the high employment were tangible (in improved scope and quality of service delivery, for instance). Unfortunately, the evidence does not support such a positive version of the government expansion story. The government has not dramatically improved its capacity to afford such a large workforce and service results do not appear better in the past decade. Furthermore, there seems to be little de facto control in the civil service regime, reflected in a festering problem of ghost workers and arrears across government. Audits have found ghost workers in fields as varied as health, policing and education; the most recent findings are of thousands of ghost teachers and hundreds of ghost schools. Arrears are also commonplace, again in many different areas of government activity. Dating back to the early 2000s, one can find civil

13 Andrews (2003b) shows that reforms are commonly in tension; decentralization reforms especially often yield conflicting messages for those trying to introduce fiscal stability. See also Andrews and Hill (2003) and Andrews and Schroeder (2003). 
Table 2: Limits and gaps in Uganda's public sector reform results

\begin{tabular}{|c|c|c|c|c|c|c|c|}
\hline \multirow[b]{2}{*}{ 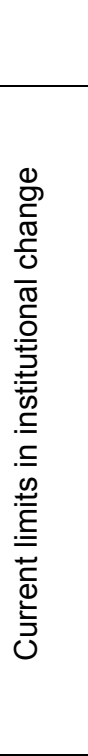 } & \multicolumn{2}{|c|}{$\begin{array}{l}\text { Civil service reform }{ }^{(1} \\
\text { and government performance }\end{array}$} & \multicolumn{2}{|c|}{$\begin{array}{l}\text { Public financial } \\
\text { management reform }\end{array}$} & \multirow[b]{2}{*}{$\begin{array}{l}\begin{array}{c}\text { Revenue administration } \\
\text { reform }{ }^{3}\end{array} \\
\text { - Tax collection } \\
\text { stagnated since late } \\
\text { 1990s. } \\
\text { - Has not reached } 14 \% \\
\text { of GDP (vs. African } \\
\text { average of } 20 \% \text { ) in any } \\
\text { year except } 2011 / 12 \\
\text { (due to one-off additions } \\
\text { from oil revenues) } \\
\end{array}$} & \multirow[b]{2}{*}{$\begin{array}{l}\begin{array}{c}\text { Procurement } \\
\text { reform }\end{array} \\
\text { - Scores for capacity, } \\
\text { operations, and } \\
\text { transparency in the } \\
\text { system are } 80 \text { of } 120, \text { or } \\
66 \% \text {; }^{(9} \\
\text { - Bids take over a year to } \\
\text { complete; } \\
\text { - Only } 1 \% \text { of contracts } \\
\text { completed within } \\
\text { budgets; } \\
\text { - Only } 29 \% \text { completed on } \\
\text { time; } \\
\text { - Only } 17 \% \text { of MDA } \\
\text { contracts with complete } \\
\text { procurement records in } \\
2011 / 12 ;(10\end{array}$} & \multirow[b]{2}{*}{\begin{tabular}{|c} 
Anti-corruption \\
reform
\end{tabular}} \\
\hline & $\begin{array}{l}\text { - Govt. size grown } \\
\text { since 1996; } \\
\text { - Uganda has } 71 \\
\text { cabinet ministers; } \\
\text { - Between } 290 \text { to } \\
320 \text { thousand govt } \\
\text { employees; } \\
\text { - No. of ghost } \\
\text { workers higher than } \\
\text { before; }{ }^{6} \\
\text { - Arrears } \\
\text { commonplace; } \\
\text { - Controls seem } \\
\text { lacking. }\end{array}$ & \begin{tabular}{|} 
- National plans not \\
been 'consciously \\
implemented' \\
- Performance low; ${ }^{(7}$ \\
$56 \%$ of National \\
Development Plan \\
performance \\
targets are not \\
even assessed; \\
- $22 \%$ of targets \\
assessed and \\
achieved; \\
-1 of 16 'national \\
core projects' \\
achieved, and 10 \\
(63\%) are off track \\
or not assessed \\
\end{tabular} & $\begin{array}{l}\text { - Actual } \\
\text { implementation } \\
\text { complies only } 50 \% \\
\text { with PEFA 'good } \\
\text { international } \\
\text { practices'; } 8 \\
\text { - Current spending } \\
\text { exceeds domestic } \\
\text { revenues; } \\
\text { - Country has no } \\
\text { domestic fiscal space } \\
\text { for infrastructure } \\
\text { spending }\end{array}$ & $\begin{array}{l}\text { - Transparency of } \\
\text { budget execution } \\
\text { only } 48 \% \text { on OBI; } \\
\text { compared with } 73 \% \\
\text { for transparency in } \\
\text { budget preparation } \\
\text { - Limited information } \\
\text { on actual spending }\end{array}$ & & & \\
\hline \multirow[b]{2}{*}{ 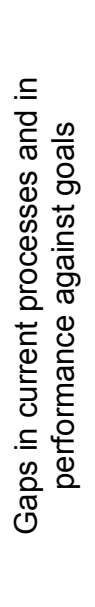 } & \multirow{2}{*}{$\begin{array}{l}\text { - Significant gap } \\
\text { between the size of } \\
\text { Uganda's govt. and } \\
\text { its goals set in the } \\
\text { early } 1990 \text {; } \\
\text { - No. of ministers } \\
\text { and govt. } \\
\text { employees } \\
\text { between } 70 \% \text { and } \\
100 \% \text { higher than } \\
\text { targets set }{ }^{(11} \text { and } \\
\text { controls ineffective. }\end{array}$} & \multirow{2}{*}{$\begin{array}{l}\text { - } 78 \% \text { of National } \\
\text { Development Plan } \\
\text { targets either not } \\
\text { assessed or not } \\
\text { achieved; } \\
\text { - Govt. has a } \\
\text { performance plan } \\
\text { but half of it has no } \\
\text { value (with no } \\
\text { assessment) and a } \\
\text { quarter of it reflects } \\
\text { explicit implement- } \\
\text { ation failure; } \\
\text { - Similar failure rate } \\
\text { for } 63 \% \text { of 'national } \\
\text { core projects' }\end{array}$} & $\begin{array}{l}\text { - Gap between laws } \\
\text { and implementation } \\
\text { of the laws is } 20 \%\end{array}$ & $\begin{array}{l}\text { - Gap between } \\
\text { transparency in } \\
\text { formulation and } \\
\text { execution is } 25 \%\end{array}$ & \multirow{2}{*}{$\begin{array}{l}\text { - Govt. revenue low, with } \\
\text { a } 25 \% \text { dependence on } \\
\text { external financing and a } \\
\text { financing gap; } \\
\text { - This limits infrastructure } \\
\text { and other expenditure } \\
\text { (which is lower than in } \\
\text { most other African } \\
\text { countries) }\end{array}$} & \multirow{2}{*}{$\begin{array}{l}\text { - Gap between laws and } \\
\text { capacity to implement } \\
\text { laws is } 33 \% \text {; } \\
\text { - Gap between laws and } \\
\text { actual implementation is } \\
\text { even larger: } \\
\text { - In } 2011,99 \% \text { of } \\
\text { contracts were over } \\
\text { budget; } \\
\text { - } 71 \% \text { were overdue time } \\
\text { - Average bid took } 7 \\
\text { months longer to } \\
\text { complete than targeted. }\end{array}$} & \multirow{2}{*}{$\begin{array}{l}\text { - Gap between laws and } \\
\text { implementation is about } \\
50 \text { out of } 100 \text {, one of the } \\
\text { largest in the world. } \\
\text { - New laws and systems } \\
\text { have not curbed corrupt } \\
\text { behaviour. }\end{array}$} \\
\hline & & & \multicolumn{2}{|c|}{$\begin{array}{l}\text { PFM results are negatively affected } \\
\text { by current gaps: Actual spending has } \\
\text { regularly deviated significantly form } \\
\text { budgets (exceeding } 10 \% \text { ). The } \\
\text { situation is worse for local govts } \\
\text { where actual spending deviates } \\
\text { significantly from budgets }\end{array}$} & & & \\
\hline
\end{tabular}

Sources and notes: See next page. 
Notes and sources to Table 2.

1) Data are drawn from the Uganda Computer Services, Ministry of Finance, Planning and Development and the UBOS (2012).

2) Data are drawn from the 2012 PEFA assessment and the 2012 OBI assessment. See www.pefa.org and www.internationalbudget.org.

3) Information drawn from various sources including ITD (2010).

4) Data are drawn from the 2007 OECD baseline procurement assessment of Uganda's system. Available at: www.oecd.org/development/effectiveness/39256199.pdf

5) Data are drawn from the 2008 and 2010 Global Integrity surveys, available at: www.globalintegrity.org

6) UBOS (2012: September) shows the official size of the civil service at 290,000.

7) Data drawn from RoU (2012).

8) The average score for dimensions that assess compliance with de jure elements of the PEFA assessment is 2.

9) The three areas assessed other than legal and regulatory framework are titled 'institutional framework and management capacity', 'procurement operations and market practices', and 'integrity and transparency of the public procurement system'. Uganda averages 2 out of 3, 2.2 out of 3 , and 1.9 out of 3 for these three areas.

10) RoU (2012, vol. 1: 100)

11) The number of ministers is also higher than all countries in Africa except for Kenya.

12) RoU (2012, vol. 1: 38) 'Domestic revenue mobilization remains inadequate, leading to continued reliance on loans and grants'.

13) As per January 2013 local govt. PEFA assessment.

society reports of such arrears bubbling onto the streets in the form of strikes or rallies by policemen, university professors, teachers, doctors, and other government employees. The official reports do not suggest that arrears are a major fiscal problem to the state, but the regularity of salary arrears (lasting for two or three months at a time) indicates that there are control and management constraints in the civil service system.

These problems persist despite many institutional 'solutions' that were meant to address them (including a commitment control mechanism and the IFMIS). ${ }^{14}$ The new IPPS is also meant to help enhance control, but it is too early to determine if it will succeed or produce the same limited results of past technical interventions.

The limit of past reforms and ineffective nature of the public administration are further evidenced when looking at performance management and plan implementation in Uganda. Whereas the country was a continental leader in introducing different versions of resultsmanagement and government-wide planning, it has not proven very effective at producing results or implementing plans. Performance mechanisms (including budgets for organizations and contracts for managers) are still not used effectively (with budget allocations still not tied to results, for instance) (Williamson 2003: viii). Beyond this, national plans have not been 'consciously implemented' and performance is low (RoU 2012); 56 per cent of national development plan performance targets are not even assessed; 22 per cent of the targets that have been assessed have not been achieved; only one of 16 'national core projects' has been achieved, and ten ( 63 per cent) are off track or there is no assessment.

14 A February 2006 IMF Country Report (No.06/43) reflected on the failure of the first of these and potential of a second. On page 2, it reads, 'The Commitment Control System (CCS) was adopted in the late-1990s to limits spending commitments at the ministry level to within their cash allocations. However, arrears continue to accumulate under the CCS. IN 2004/05, an estimated UGX32 billion of new arrears were accumulated. The government is currently rolling out an integrated financial management system (IFMS) that should allow better tracking and control of arrears. The new system appears to be effective in pilot ministries'. 
In short, there seems to be a gap between the civil service and public management systems that exist in form and their functionality or impact. This gap is most evident when considering the expectations citizens have of service delivery and execution by government. Data on this is difficult to come by, with recent Afrobarometer surveys providing the most accessible source. 15 According to this source, citizens have very little faith in the government's ability to do key things; 79 per cent think that government manages the economy 'very badly' or 'fairly badly'; 77 per cent answer similarly when asked if government handles the problems of poverty well; 82 per cent think government manages equity issues badly; 51 per cent and 44 per cent view government healthcare and education service provision negatively; 54 per cent feel that government handles water and sanitation services 'very' or 'fairly' badly; 67 per cent and 68 per cent note that government handles maintenance of national roads and bridges and local roads poorly; 78 per cent think similarly for electricity supply; and more. These data need to be treated with care and are used here simply to show that there is a deficit of trust and expectation on the part of citizens - meaning they do not see the government as effective even after three decades of reforms and the adoption of 'best practice' mechanisms in the civil service and planning realms. The government simply looks better than it is after these reforms, and the gap needs to be closed.

Similar gaps also exist in the area of public financial management (PFM). Whereas reforms have produced a PFM system where laws and processes comply with over 70 per cent of the 'good international practices' measured in the multi-donor PEFA assessment, actual implementation complies only 50 per cent with these practices. 16 This means that Uganda has many areas in its PFM system where laws and processes are not being properly used or implemented. The PEFA scores are high (A or B) when asking if a budget calendar exists but the scores are low (D) when assessing if the budget preparation has actually been completed in the calendar period. 17 The gap between the de jure form and de facto functionality is quite significant and can be found throughout the PFM system (see actual figures for de facto scores in Appendix Table 1). Various authors have written about it over the years as well, providing further evidence of its existence and importance. In 2003, for instance, Williamson (2003: viii) identified that whereas government had invested in adopting an output/outcome budgeting system, and 'Sectors are required to analyse past performance of outputs and outcomes ... and to set future output and outcome targets to be achieved over the MTEF period ... The Ministry of Finance has tended to continue with incremental budgeting ... and not allocate funds on the basis of performance'.

Another gap exists between the quality of upstream budget preparation mechanisms and downstream budget execution mechanisms. This is reflected in PEFA scores (where the budget preparation mechanisms score an average of 2.8 of 4 but execution mechanisms score 2.1 ) and in the recent OBI data. The OBI data show that Uganda has significant transparency in the way it produces its budgets and communicates what it plans to spend (scoring 73 per cent on the questions about transparency in budget preparation). However, it only satisfies 48 per cent of the requirements associated with transparency of budget execution (where the

15 These are 2012 data. www.afrobarometer.org/files/documents/summary_results/uga_r5_sor.pdf

16 This statistic is based on the authors' analysis of the PEFA data using methods developed in Andrews (2011). This method sees one identifying the dimensions of the PEFA analysis that relate to de facto performance (where a B is possible only if a government actually produces something with the systems it has in place). Uganda scores 2 out of 4 on average when looking at such dimensions.

17 The relevant dimensions are 11.i and 11.iii. 
focus is on transparency of what was spent and what results ensued) (see also Appendix Table 1). This means that reforms have provided an effective window onto the promises of government but leave it very difficult to see the actual activities and impact of government. It also means that PFM systems are not providing the kind of information during implementation that government needs to ensure that spending is effective and efficient, that goals are being met, and that lessons are being learned about how to properly execute complex public sector spending plans. The continued weakness of these implementation systems - even after decades of reform - manifests in the regular deviation of actual spending from budgets (this deviation regularly exceeds 10 per cent) and is a major reason why service delivery remains deficient and why the country continually struggles to find domestic fiscal space for important spending (like infrastructure spending).

The gap between appearance and reality is apparent in the area of revenue administration as well. Whereas the country has a revenue agency that satisfies many 'good practice' organizational criteria, for instance, it is also considered very corrupt. The 2012 Afrobarometer survey found that 69 per cent of respondents had 'a little' to 'not at all' trust in the Uganda Revenue Authority and 90 per cent felt that 'some', 'most' or 'all' URA officials and other tax collectors were corrupt. This perspective has been reflected in various surveys and studies over the past fifteen years, with a 2007 Transparency International study showing the URA as 'the most corrupt tax institution in East Africa'.18 The URA performed similarly poorly on the 2010 East African Bribery Index, which portrayed it as the most corrupt public entity in Uganda. 19

Beyond this, the URA has not been very effective as a revenue collection agency. Collections stagnated after 1999 and have been in a band between 11 and 13 per cent (of GDP) in every year except 2011 (when there was growth because of one-off deals and early impacts of oil revenues) (AfDB 2010; Ronald 2011: 1). The percentage is low compared with other African countries - where the average tax to GDP ratio exceeds 20 per cent in east Africa and beyond (Drummond et al. 2012; Ronald 2011: 1). 20 The problem of low government revenue means that Uganda is heavily dependent on external financing (with about 25 per cent of its budget funded by outside agencies). The country has a perpetual financing gap that limits infrastructure and other expenditure (which is lower than in most other African countries).

Various observers argue that the problems in the URA (with corruption and weak tax collection) fester because tax reforms have not addressed key constraints. These include a continued reliance on informal markets, low 'tax morale', low trust in government and resulting failures to pay tax, low political support for revenue reforms, and bureaucratic and political influence of the URA (Kidd and Crandall 2006: 32). In respect of the last issue, observers note that the 'semi-autonomous' URA is anything but, and is rather 'prone to close

18 The precise quote is from an article by Yasiin Mugerwa. The 2005 Afrobarometer showed that 60 per cent of the public believe tax officials are corrupt (Ittner 2009: 66). The general problem of corruption in Uganda's URA discussed by Fjeldstad (2005). See www.jamiiforums.com/business-and-economic-forum/33049$\% 91$ uganda-revenue-authority-is-most-corrupt-e-african-tax-body\% $\% 2$.html

19 See article in The Independent, 2 August 2010.

20 It is interesting to note interviewees in the URA disagreed with the idea that they had low levels of revenue collection in 2005. When asked if the URA had helped increase tax revenues at the time, they allotted themselves full marks (10 of 10) (Kidd and Crandall 2006: 91). The record at the time did not reflect such sentiment at all, with revenue to GDP ratios in 1997 being 12 per cent and sitting at about 13 per cent in 2004 (Kidd and Crandall 2006: 93). 
oversight and patronage by the national political leadership' (AfDB 2010:6). ${ }^{21}$ There is a further perception that tax incentives and exemptions have been imposed on the URA by political leaders - even though the URA's semi-autonomous status should limit such influence. While many perspectives on this issue are possible, it seems fair to conclude that Uganda's revenue reforms have not yielded the results that were needed - there have been limits in reform and gaps exist between what the reforms delivered on paper and how they function in practice. Ali Ronald (2011: 19), a Makerere student, wrote as much in 2011, observing 'The continued poor domestic revenue mobilization despite many tax reforms established since the 1990s....'.

The area of procurement offers similar evidence. Most recently, for instance, Cornelia Sabiiti from the PPDA noted that the new processes introduced since 2002 are not being implemented.22 An assessment showed decreased compliance with process requirements between 2008/09 and 2011/12. Compliance was at around 40 per cent for contract award and record-keeping (meaning that only 40 per cent of contracts were awarded and records kept according to the mandated processes). The PPDA targeted 100 per cent compliance with complete record-keeping requirements but in 2011/12 only 17.1 per cent of the contracts complied with this. (The highest level of compliance was 32 per cent in 2008/09, which shows that new formal processes have never been well implemented and that the gap between form and function is growing). The assessment also found that the average time taken for all kinds of bids was much longer than the government-set targets. The target for open international bidding is 155 days but the average performance in 2011/12 was 341 days. The lowest level was 206 in 2008/09. This is an average delay of seven months above the target of five months - a significant performance gap. The target for open domestic bidding is 132 days but the average performance in $2011 / 12$ was 334 . The lowest level was 162 in 2008/09. In 2011/12 only 0.7 per cent of assessed procurements were implemented within the budget estimate (monetary allocation for the contract) and only 29.4 per cent of the contracts were completed within the original contract time; 99.3 per cent were over budget and 71 per cent were over time and late.

Beyond this, the PPDA's 2010 Procurement Integrity survey reports that suppliers spend up to 20 per cent of contract amounts on corrupt payments, up from 10 per cent in 2008 . This amounts to about US\$240 million annually in bribes. Such problems exist despite the many 'best practice' reforms introduced in Uganda. This is reflected in comments from Anja Kramer of KfW and Howard Centenary (from the World Bank) who note that various new mechanisms are not working well (the limited parts of reform are shown in italics, added by the authors for emphasis) (New Vision 2012):

[The] [e]stablishment of a procurement grievance handling mechanism is another achievement...However, the use of this grievance mechanism is still limited, with only about 30 complaints received annually at PPDA for possible fear of bidders being persecuted through denied future opportunities... PPDA has improved its monitoring system and has to date conducted 329 audits in 221 procuring agencies

21 See also Fjeldstad (2005) and Therkildsen (2004).

22 Cornelia Sabiiti, the Executive Director of the PPDA presented a powerpoint titled 'Performance of the Public Procurement and Disposal System in Uganda' at the Public Procurement Symposium \& Exhibition, $19^{\text {th }}$ to $20^{\text {th }}$ September 2012. The information in this presentation is reinforced in the PPDA's public announcement supporting the 2012 Public Procurement Symposium \& Exhibition, published on 19 September 2012 in New Vision (PPDA Supplement 33). 
since its establishment in 2003...The task ahead is to increase monitoring and audit coverage to ensure that a substantial proportion of the budget expended through procurement is audited by both PPDA and the Auditor General... While these achievements are laudable, some challenges that constrain the achievement of the main objectives of value for money and efficiency in service delivery still remain. Corruption especially through bribery in procurement is one of the major vices that impedes achievement of value for money ... Procurement delays also contribute to ineffective service delivery ... There are weaknesses in contract implementation especially in performance by contractors...

These sentiments are reflected in various articles on procurement in Uganda, including Agaba and Shipman (2007) and Basheka (2008) who note that procurement laws are not being implemented in local governments (in particular). Basheka's survey across districts shows fundamental challenges were not dealt with, including the lack of functional and effective procurement and disposal units (created in name but with no appointments) and problems in carrying out market surveys (and ensuring local markets could facilitate the kinds of procurement being planned) and collusions in bid preparation among district staff. These kinds of constraints are reflected in the weak scores Uganda gets on OECD procurement assessments of capacity, operations, and transparency in the system. In 2007 the scores were 80 of 120 (or 66 per cent) for these factors (averaging 2 out of 3 as a score in Appendix Table 2). Given that laws satisfied 99 per cent of OECD survey requirements (as shown in Appendix Table 2), the gap between laws and the capacity to implement laws was 33 per cent. The gap between laws and actual implementation is even larger, given that (as already shown in 2011) 99 per cent of contracts were over budget, 71 per cent were overdue, and the average bid took seven months longer to complete than targeted. This reveals a major challenge of reform implementation which is also borne out in Global Integrity data. This shows that Uganda scores much lower on questions asking about practice than it does on questions asking about legal reform (see Appendix Table 3).

The situation is similar when looking at anti-corruption reforms. As already shown, Global Integrity gives Uganda 98 out of 100 on the quality of anti-corruption laws. The country is in full compliance with 95 per cent of the questions asking about the quality of laws. But it scores only 51 of 100 when the Global Integrity survey asks about implementation of laws, with full compliance on only 11 per cent of the questions about implementation and practice (see Appendix Table 4). The gap between form and function is 47, which is nearly twice as high as it is in places like Sierra Leone (Kenya is at 30), showing that Uganda has the best anti-corruption laws in Africa and one of the poorest records of implementing such. This is a problem with real implications for Uganda. Costly corruption crises are commonplace, and corruption is considered pervasive. One needs only to look at recent newspapers to get a sense of the recent scandals and their implications on the government and economy:

- At least US\$10 million of Global Fund monies was misappropriated in 2006, leading to constraints in the supply of malaria and tuberculosis drugs. The country also lost significant funding from donors because of this.

The bicycle scandal of 2011 saw payments for 70,000 bicycles made without any bicycles being delivered.

UGX60 billion went missing from the Microfinance Support Centre in a three-month period in 2011. 
- The pensions scandal of 2012 involved the loss of UGX169 billion meant to finance outstanding pension claims.

- In 2012 UGX5 billion in donor funds intended to fund the Peace Recovery and Development Plan for Northern Uganda went missing, causing a variety of donors to freeze development aid.

The variety of areas in which crises have occurred shows how widespread corruption still is in Uganda. Transparency International's Corruption Perceptions Index provides further evidence of this. The score was 29 in 2012 (out of 100), showing that the level of corruption is high. There has been a significant acceleration in corruption as well, and the country now sits at 130 of 176 countries (dropping from 111 of 179 in 2007). Reflecting on such situation, the thinktank Global Integrity describes Uganda as the place where there has been 'tough talk, much noise, no improvement'.23 Ittner (2009: 64) writes similarly: 'This trend indicates that the perceived level of corruption has hardly, if at all, improved during the last decade despite numerous and highly publicized attempts at reform'.

Ittner notes that reforms have had limited success partly because they did not deal with the contextual realities of corruption in Uganda. He argues, for instance, that the main enforcement body is the police, which is widely considered one of the most corrupt entities in Uganda. ${ }^{24}$ Ittner outlines various reasons why police corruption festers, including low pay levels, poor leadership, corruption at the top of the police force, political influence over key appointments, and more. He notes that government has adopted reforms designed to address these kinds of challenges in the police force, but with limited success-because these reforms were themselves not properly implemented. In 1996, for instance, the National Fraud Squad was created to investigate government and parastatal corruption cases. But 'it suffers from lack of equipment and has only limited capacities and little incentives for accountable and transparent working practices' (Langseth and Pezzullo 2000; Flanary and Watt 1999: 527). Ittner (2009: 86) argues that, the current consensus is that the squad remains largely ineffective due to these constraints and is unlikely to have any impact on the level of corruption which should make it clear that Uganda's corruption problem will not be solved by creating new laws for the (flawed) police to (not) enforce.

\section{$4 \quad$ A less limited reform agenda in the future}

There are various ways that a reader could respond to the argument and evidence provided so far. Some may get stuck questioning the validity of individual indicators used to tell the story. This would be an unfortunate approach to take. While there are definitely questions to ask about individual indicators, the pattern of limited reform with gaps is not reflected in just one measure. Instead, it manifests as a pattern across multiple areas of reform. This pattern should be taken seriously, especially as it resonates with perspectives recently shared by government officials, civil society members, and external donors. Introductory quotes to this paper stand as examples:

\section{3 www.globalintegirty.org/node/385}

24 This is reflected in Afrobarometer data and in government's own data, like the 2003 National Integrity Surveys, which show that half or more respondents see the police as corrupt-given actual experiences of having to pay bribes (not perceptions). 
- John Kiyaga-Nsubuga of the Uganda Management Institute (ISS 2008: 8) noted recently that, 'On the one hand...the legislation is better, the monitoring and evaluation systems are better ... but on the negative side is the issue of impacts... That is where the problem is'.

- The journalist Oscar Otindo (2012) opines that Uganda faces the problem of 'let's pass new laws' where 'Laws are being passed every single day yet the ones present are neither effective nor implementable'.

- Roberto Ridolfi, the Head of the European Union Delegation to Uganda (cited in Mulondo), stated that, "We need more action than talk. Uganda has the best Constitution and some of the best procurement laws, a robust public finance management system and institutions capable of administering sanction. Why are all these not working?'

Readers could read these comments and agree that some action is needed to increase the impact of Uganda's reforms. A response of this sort could see proposals that look very much like the old reform ideas, however; with many new laws, best-practice mechanisms and the like introduced as 'solutions' (much as one sees in Figure 1). It appears that such approach is still prominent in the Ugandan context. For instance, the International Monetary Fund recently called for government to strengthen the Public Finance Bill to ensure more stringent sanctions against public officials involved in misappropriating finances. They also called for the creation of a treasury single account to centralize fund flows. These 'solutions' resemble those introduced after prior crises; including the Anti-Corruption Bill and Whistle Blower Bill in 2008 (after the Global Fund scandal). These past 'solutions' were not properly implemented, however, and contributed to excellent-looking systems and formal mechanisms that do not function and do not solve real problems. Proposing new externally devised 'solutions' for future reforms is likely to yield the same limited reform results and even increase the gaps between form and function (Andrews 2012b).

Instead of proposing 'more of the same', readers might determine that a new reform approach is needed to build on the reform gains to date but also overcome the limits of past reforms and close the gaps that now fester. Such an approach is proposed in this final section. It builds on recent ways of thinking about doing complex institutional change and is called problem-driven iterative adaptation (PDIA) (Andrews 2013; Andrews et al. 2012). PDIA is a process of doing reform that involves three key dimensions:

It is problem driven.

It emerges through step-by-step activities with rapid, results-oriented learning.

It involves broad sets of agents from the outset.

\subsection{A problem-driven reform agenda}

Uganda has shown a predilection for adopting 'best practice' type reform solutions that look impressive but often fail to work. Recent research suggests that such reforms often fail to address the real problems in complex contexts, or are beyond the local contextual capacity to implement, or face too much political opposition in implementation. All of these factors seem to play a role in limiting the success of Uganda's reforms to date, which suggests that a new approach is needed. This new approach should be less focused on adopting external solutions and more on solving problems that local agents care about. A focus on problems does three things. First, a clearly defined problem helps to draw the kind of attention and introspection 
needed to make institutional reforms work. Second, problems focus a search on solutions that will actually work in a given context (where success is measured as 'problem solved' rather than 'solution adopted). Third, problems are the rallying point for creating effective coalitions commonly required for public sector change.

The proposal at hand is to use some of the gaps identified in this document as 'problems' that allow entry points to deeper and more meaningful reform in the future (see Table 2). This could be the gap between planned programmes in the national development plan and their actual execution, or it could be the current gap between formulated budgets and actual budget outcomes, or it could be the gap in revenue collection (between what is needed to foster more fiscal independence and what is actually currently being collected). One could also identify gaps in the areas of procurement and corruption that relate (for instance) to the time and cost of procurement, provision of key goods and services (like textbooks or medicines) or poor record-keeping.

The first step in problem-driven reform would involve 'constructing' the problem-or packaging it in a way that ensures it gets the attention it demands. This packaging could centre on using data and other evidence to show the extent of the problem and constructing a narrative that cannot be ignored and that ensures the problem is prioritized as a focal point. This narrative tells the story about how severe the problem is, why it matters, and what it will look like when the problem is solved. This is not a step that should be taken for granted and is not a step that one sees in evidence in most of Uganda's public sector reforms of the past. For instance, the revenue administration reforms were hatched in the early 1990s as a direct response to the problem of low revenue collection and high levels of fiscal dependence. The problem was not properly constructed, however, into a story that had a chance of surviving the first few years of the URA's mandate. After that time it seems that the imperative of collecting revenue was forgotten and the focus shifted to creating an impressive looking organizational façade behind which officials could pursue other interests.

Right now, however, one could re-frame the reform focus by using data to re-construct the problem of low revenue collection and fiscal dependence as shown in Table 3. This kind of problem construction could be used to invigorate reforms that build from where Uganda currently is. For instance, the PPDA could use some of its new data to identify a particular problem like the average amount of time it takes to complete a procurement transaction. They could note that the current time is five months over the legal requirement and could set a

Table 3: A proposed example of a 'problem' being constructed

\begin{tabular}{ll}
\hline Basic problem & Revenue collections are low \\
\hline Data to reflect severity of the problem & $\begin{array}{l}\text { Collections have been at 13-14 \% of GDP or below for a decade, } \\
\text { compared with rising collections that exceed 20\% of GDP in most } \\
\text { African countries now }\end{array}$ \\
Why does the problem matter? & $\begin{array}{l}\text { Domestic collections currently only fund about 70\% of budgeted } \\
\text { funds, resulting in continued dependence on foreign finances. }\end{array}$ \\
& $\begin{array}{l}\text { Budgeted funds are insufficient (about 19\% of GDP, } 3 \% \text { lower than } \\
\text { the average in Africa) to allow government to address social and } \\
\text { infrastructural demands, such that low revenues are a handbrake } \\
\text { on development }\end{array}$ \\
& By 2020 the tax to GDP rate would be at 20\% \\
\hline $\begin{array}{l}\text { What would the problem look like } \\
\text { solved? }\end{array}$ & \\
\hline
\end{tabular}

Source: Authors' proposed approach. 
target for 'problem solved' being an average time that complies with legislation. Once constructed, the problem would become the basis of communication about reform. A communications strategy would be required to draw key stakeholders into the reform process and to ensure one has enough authority to start effecting real change. This kind of communication strategy often begins with a stakeholder analysis where reformers clarify whose support they actively need and whose potential resistance they need to manage.

While pursuing such communication, reformers should also be initiating a process of finding contextually relevant solutions to the problem at hand. Given that the problems have not been solved by externally sourced solutions in the past (given the evidence of gaps following such reforms, which are common in many countries 25 ) it should be accepted that a local process of finding and fitting reform is required (and not a 'simple' reform solution in itself). The first step in this process would involve 'deconstructing' the problem under consideration. This requires using a tool like the problem tree or Ishikawa analysis; where one identifies the various causes of the complex problem. Figure 2 shows a potential problem tree diagram related to revenue reform in Uganda, with the 'tree head' providing a clear statement of the problem at hand and why it matters. The diagram allows one to nominate many possible reasons why the problem is festering, meaning that many different perspectives can be accommodated. In respect of revenue management in Uganda, for instance, one might say that the low collections are caused by corruption in the URA, a culture of no payment, too many tax breaks, and other reasons. On each of these 'branches' one could identify further sub-reasons that detail these reasons. For example, there are many possible factors that contribute to corruption in the URA (including salary levels, discretion of tax collection processes, failure to follow up on questionable transactions, and more). Identifying all of these branches and sub-branches helps one break the problem down-given how it plays out in the Ugandan context - and then helps to think about where, when and how to intervene.

Figure 2: A proposed example of a problem being 'deconstructed'; revenue collection

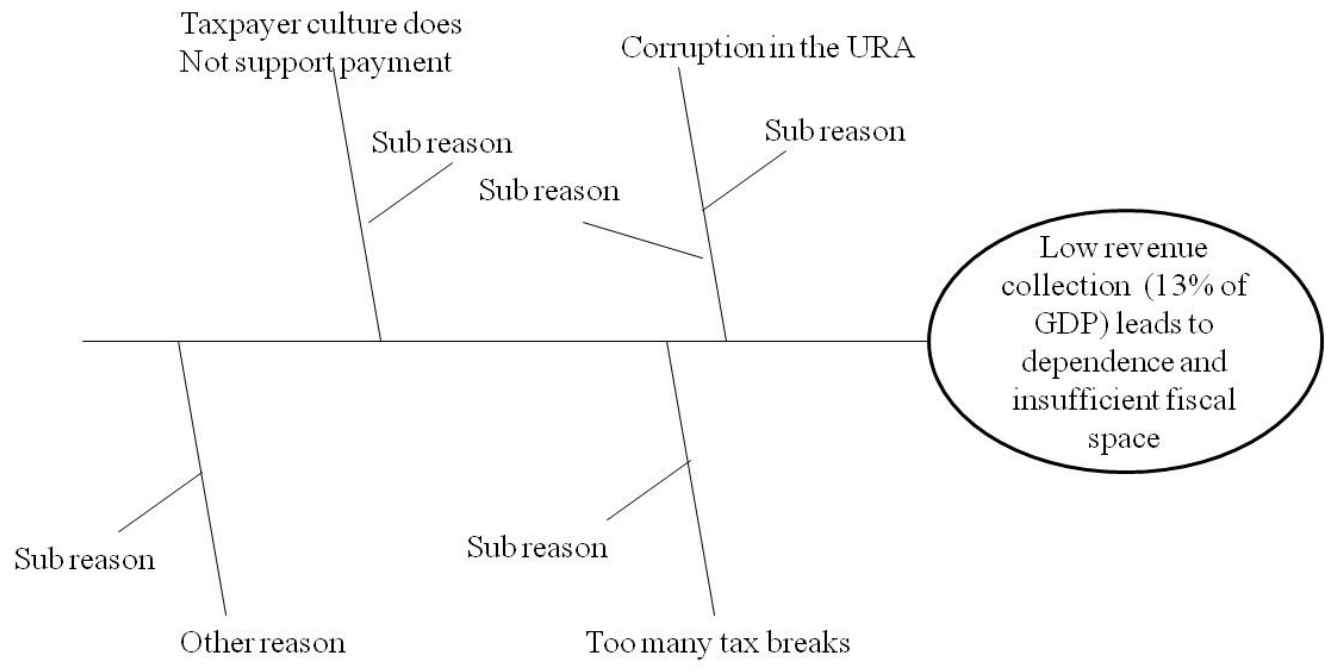

Source: Authors' proposed approach.

25 External 'solutions' are often adopted because outside messages say that they are the 'right' reforms to adopt. But they cannot be implemented because of on-the-ground realities-norms are not the same in the targeted setting, capacities do not support the new best practice, and political pressures often make the proposed change impossible. Under such conditions one should expect decoupling - where the new practice is adopted in name but operational systems and behaviour remain the same. See Andrews (2011, 2012b, 2013). 


\subsection{An agenda of step-by-step activities with rapid, results-oriented learning}

The kind of analysis implicit in a full problem tree analysis should be done in teams of Ugandan officials (the type of agents who should be involved are discussed in more detail later in this paper). Such analysis shows the complexity of problems and should make it apparent that external best-practice ideas never provide 'the solution' to the complex problem. A semi-autonomous revenue agency cannot address the informality issue undermining revenue collection, for instance, or solve problems of locally accepted corruption. These dimensions of the problem - and others - can only be effectively addressed through a process of finding and fitting locally relevant solutions. Given that these solutions have not emerged in the past - evidenced in the limits and gaps already discussed-Uganda probably needs an iterative process of finding and fitting. This would involve iterative experimentation with multiple options, and learning about what works and why (instead of a common process that identifies one answer upfront and then embarks on a fixed project schedule to adopt such solution-which often ends up limited).

This process begins with brainstorming about the entry points for reform. This involves asking serious questions about the contextual space for doing reform on different 'branches' of the problem tree. Some 'branches' would allow more active engagement than others, given that the building blocks of change are already in place. Past research suggests that these building blocks include (i) political authority supporting change, (ii) acceptance of the need to change, and (iii) the ability to actually come up with new ideas and implement such (Andrews 2008, 2012a, 2012b). Figures 3 and 4 illustrate the idea that reform and change are possible only where there is sufficient authority, acceptance and ability-combining to create 'space for change'. In such situations one can actively experiment with new ideas. Where there is no overlap between the three building blocks, one cannot immediately start with introducing new ideas and instead one should work to establish and grow the 'space for change'. In Figure 4, for instance, there is obviously a dearth of ability which is compromising the reform space. A reform agenda in this context would begin by building some basic abilities to grow the reform space (not with an actual 'reform').

This might seem a simple observation, but the key takeaway is that reform sometimes starts with introducing new ideas into a pregnant space (as in Figure 3) but often reform needs to start with creating the space itself (as in Figure 4).

This kind of contextual analysis is more art than science; but it is designed to help reform teams identify where they can enter on the problem tree and what the first steps of such entry should look like. The team might determine that there is space to introduce reforms to deal with tax breaks, for instance (given that authority, acceptance and ability are in place) but they might conclude that there is no such reform space to address issues of informality and URA corruption (possibly because they do not have authority to act). Given such conclusions, they could agree to start aggressive reforms in the area of tax breaks and to start building authority to create the reform space needed to address the informal payments and URA corruption issues.

Once this kind of contextual analysis has been done, the team should be encouraged to continue brainstorming about potential interventions they could adopt, quickly and with existing resources, in each area. One approach to this brainstorming draws from techniques used by the Rapid Results Institute. It has the team take note of what success would look like in each area of reform and when this could be meaningfully achieved. Then the teams 


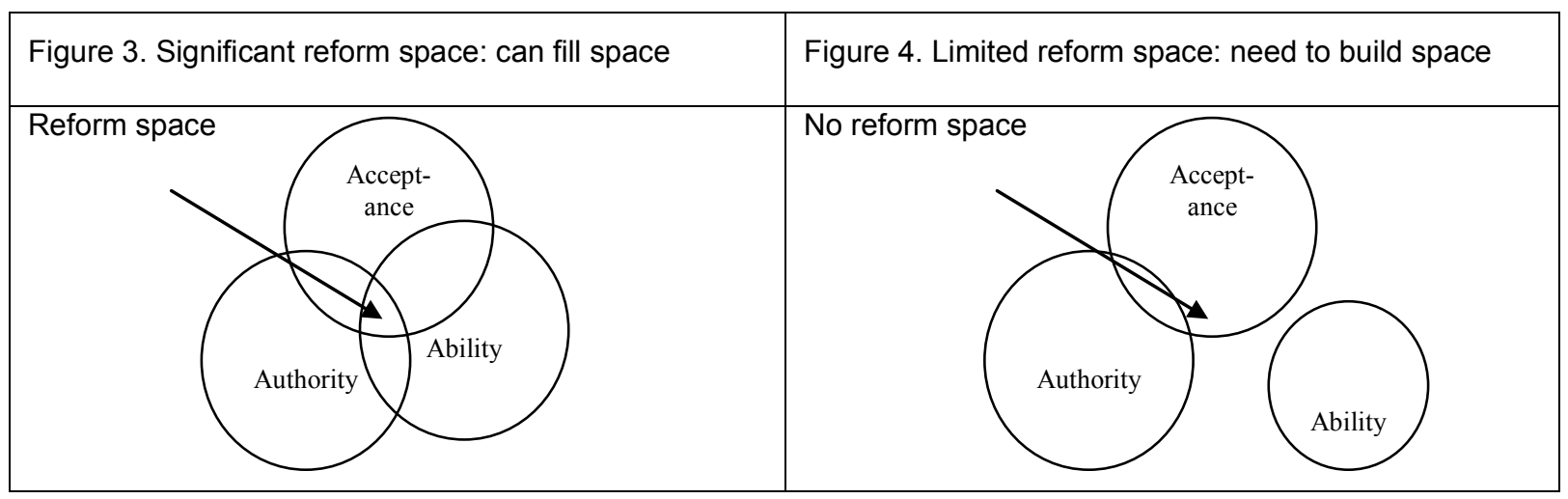

Source: Authors' proposed approach.

identify steps that they think would be needed to achieve such success, working backwards from the end goal to the present in three month increments. Teams should be encouraged to present two or three pathways in this exercise, where they propose different sets of ideas for reform. They could set a goal of garnering authority to address corruption in the URA (from the president, minister of finance and URA head) in six months, for instance (given that this authority is needed to foster full-fledged reform). They could simultaneously identify the goal of reducing tax breaks by 50 per cent in a year's time (with the idea that revenue collection would increase a year later, as in Table 4). Working backwards, they might identify that the last step in one 'pathway' towards such process would be 'passing legislation that reduces specific tax breaks'. The step before this might be drafting a formal bill for the legislature (in which full details are provided about the tax breaks to be reduced). The step prior to this might involve agreeing the precise tax breaks to eliminate, in a formal document approved by key decisionmakers in the executive. The step prior to this would require doing a careful analysis of all tax breaks and proposing which ones to eliminate (based on clear criteria). An alternative pathway could focus less on doing an analysis of tax breaks and rather stress enforcement of tax audits that currently find companies abusing existing tax breaks (which might itself lead to lower revenue losses from existing tax breaks).

This kind of exercise ensures that a reform agenda emerges that is locally relevant and problem driven, and tied to results that are not too distant. It allows reform teams to map out a reform agenda for a measured period, but not in any kind of overly determined fashion. It also gives reform teams their 'first steps' and a timehorizon for achieving such. This is vital, as it becomes the basis for real action and implementation and ensures that reform thinking is quickly translated into reform engagement and results.

The reform teams would mobilize real action to take their first steps on both pathways, probably through two sub-teams charged with doing the identified tasks (the analysis of tax breaks and the stock take of tax audits on companies). Coaches would be used to ensure that the sub-teams work aggressively to achieve the tasks in the time allotted, breaking even these tasks down into smaller weekly tasks for individuals to do and then brokering regular team meetings where all members would report back on their progress. These report-back sessions are designed to ensure rapid feedback about the reform process (what is working, what is not working, why, and what can be done to ensure success). The rapid feedback allows for onthe-job learning in the teams, promotes a vigorous momentum in the reform process, and ultimately helps to establish an adaptiveness in the reform teams (where they learn to identify and overcome obstacles in a systematic manner). At the end of three months, both sub-teams (or more, if there are more) report back on their results and what they have learned. They also have an opportunity to alter the 'next steps' reform designs they initially established to reflect 
lessons learned. Then they start addressing the second step and iteratively move towards the goal.

Table 4. An example of activity identification, related to elimination of tax breaks

\begin{tabular}{|c|c|c|c|c|}
\hline $\begin{array}{l}5 \\
\text { What step would } \\
\text { you have taken } \\
\text { first? }\end{array}$ & $\begin{array}{l}4 \\
\text { What 'step' would } \\
\text { you have taken } \\
\text { before that step? }\end{array}$ & $\begin{array}{l}3 \\
\text { What 'step' would } \\
\text { you have taken } \\
\text { before the last } \\
\text { step? }\end{array}$ & $\begin{array}{l}2 \\
\text { What would your last } \\
\text { 'step' look like to } \\
\text { achieve this success? }\end{array}$ & $\begin{array}{l}1 \\
\text { What would } \\
\text { 'success' look like } \\
\text { and when could it be } \\
\text { achieved? }\end{array}$ \\
\hline \multicolumn{4}{|c|}{ Pathway 1} & \multirow{4}{*}{$\begin{array}{l}\text { Tax breaks are } \\
\text { reduced in value } \\
\text { by } 50 \% \text { in one } \\
\text { year's time; } \\
\text { resulting in more } \\
\text { revenue } \\
\text { collections in } 2 \\
\text { years' time }\end{array}$} \\
\hline $\begin{array}{l}\text { Doing a careful } \\
\text { analysis of all tax } \\
\text { breaks and } \\
\text { proposing which } \\
\text { ones to eliminate } \\
\text { (based on clear } \\
\text { criteria); } 3 \\
\text { months from now }\end{array}$ & $\begin{array}{l}\text { Agreeing the } \\
\text { precise tax breaks } \\
\text { to eliminate, in a } \\
\text { formal document } \\
\text { approved by key } \\
\text { decisionmakers in } \\
\text { the executive; } 6 \\
\text { months from now }\end{array}$ & $\begin{array}{l}\text { Drafting a formal } \\
\text { bill for the } \\
\text { legislature in which } \\
\text { full details are } \\
\text { provided about the } \\
\text { tax breaks to be } \\
\text { reduced; } 9 \text { months } \\
\text { from now }\end{array}$ & $\begin{array}{l}\text { Passing legislation } \\
\text { that reduces specific } \\
\text { tax breaks; } 12 \text { months } \\
\text { from now }\end{array}$ & \\
\hline \multicolumn{4}{|c|}{ Pathway 2} & \\
\hline $\begin{array}{l}\text { Stock-taking of } \\
\text { company audits } \\
\text { is done, and list } \\
\text { of all companies } \\
\text { abusing tax break } \\
\text { provisions is } \\
\text { published; } 3 \\
\text { months from now }\end{array}$ & $\begin{array}{l}\text { Penalties are levied } \\
\text { against companies } \\
\text { in respect of all } \\
\text { outstanding issues } \\
\text { in audits ; } 6 \text { months } \\
\text { from now }\end{array}$ & $\begin{array}{l}\text { Court proceedings } \\
\text { and other remedial } \\
\text { actions are initiated } \\
\text { to deal with most } \\
\text { complex cases; } 9 \\
\text { months from now }\end{array}$ & $\begin{array}{l}\text { A report is published } \\
\text { and presented in } \\
\text { Parliament showing } \\
\text { follow-up results for } \\
100 \% \text { of all tax audits } \\
\text { in companies; } 12 \\
\text { months from now }\end{array}$ & \\
\hline
\end{tabular}

Source: Authors' proposed approach.

Table 5: An example of activity and learning along one of the proposed example pathways

\begin{tabular}{|c|c|c|c|c|}
\hline $\begin{array}{l}5 \\
\text { What step would } \\
\text { you have taken } \\
\text { first? }\end{array}$ & $\begin{array}{l}4 \\
\text { What 'step' would } \\
\text { you have taken } \\
\text { before that step? }\end{array}$ & $\begin{array}{l}3 \\
\text { What 'step' would } \\
\text { you have taken } \\
\text { before the last } \\
\text { step? }\end{array}$ & $\begin{array}{l}2 \\
\text { What would your last } \\
\text { 'step' look like to } \\
\text { achieve this success? }\end{array}$ & $\begin{array}{l}1 \\
\text { What would } \\
\text { 'success' look like } \\
\text { and when could it be } \\
\text { achieved? }\end{array}$ \\
\hline \multicolumn{5}{|c|}{ Pathway 1} \\
\hline \multirow[t]{3}{*}{$\begin{array}{l}\text { Doing a careful } \\
\text { analysis of all tax } \\
\text { breaks and } \\
\text { proposing which } \\
\text { ones to eliminate } \\
\text { (based on clear } \\
\text { criteria); } 3 \\
\text { months from now }\end{array}$} & $\begin{array}{l}\text { Agreeing the } \\
\text { precise tax breaks } \\
\text { to eliminate, in a } \\
\text { formal document } \\
\text { approved by key } \\
\text { decisionmakers in } \\
\text { the executive; } 6 \\
\text { months from now }\end{array}$ & $\begin{array}{l}\text { Drafting a formal } \\
\text { bill for the } \\
\text { legislature in which } \\
\text { full details are } \\
\text { provided about the } \\
\text { tax breaks to be } \\
\text { reduced; } 9 \text { months } \\
\text { from now }\end{array}$ & $\begin{array}{l}\text { Passing legislation } \\
\text { that reduces specific } \\
\text { tax breaks; } 12 \text { months } \\
\text { from now }\end{array}$ & \\
\hline & \multicolumn{2}{|c|}{ Learning and feedback processes } & & \\
\hline & $\begin{array}{l}\text { Internal review } \\
\text { sessions every two } \\
\text { weeks }\end{array}$ & $\begin{array}{l}\text { Full report on first } \\
\text { step; review of next } \\
\text { steps, every } 3 \\
\text { months }\end{array}$ & & \\
\hline
\end{tabular}

Source: Authors' proposed approach. 
The rationale behind this iterative and experimental feedback-driven process is manifold. First, it recognizes that past reform limits show that there are no routine 'solutions' and much learning is needed to find and fit relevant reforms in places like Uganda. Second, it recognizes that political support for reforms is usually limited (allowing small steps rather than large leaps) and grows with results (hence the importance of regular results, no matter how small, that show progress towards overall goals). Third, it recognizes that capabilities to implement reforms are often limited and emerge on-the-job (through small steps in which groups can learn and grow whilst limiting the risk of costly failures associated with larger projects). Fourth, it recognizes the fact that there are usually various ideas about how one should do reform and that successful reforms typically emerge as hybrids of a variety of ideas (with different 'pathways' allowing more learning and perhaps convergence on new solutions that could not be seen ex ante).

The iterative process should not be seen as something that necessarily takes long periods of time. In fact, the steps identified in the reform strategy should be tightly time-bound to ensure that results are produced in reasonably short periods. The step-by-step results and lessons guide next steps, and are the basis of building political support and growing capacity to act. If Uganda embarked on this process in a variety of reform areas the learning and results within a year would be substantial, and highly sustainable (given that the successes would have come from the work and learning of Ugandan teams). Theory shows that institutions emerge from these kinds of iterative processes, over time, given that those who have to implement and live with the new rules of the game are the ones who find such rules and fit them to their realities.

\subsection{An agenda that involves broad sets of agents, from the outset}

The discussion so far has alluded to various agents and combinations of agents needed to make problem-driven iterative adaptation (PDIA) work in Uganda. Conventional reforms often come out of narrow groups in ministries like finance or in offices like the PPDA, under the auspices of one or other key minister (like the minister of finance). PDIA requires having a broader engagement in teams and coalitions of reformers, from the outset. The broader groups are both technical (actual reform teams mentioned above) and political (coalitions of ministers and other political leaders who authorize and support the process).

Broad groups of reformers are considered necessary because change is demanding. Individuals and small, tightly knit groups of technical specialists are unlikely to have all the functional attributes required to make change happen. For instance, those who design reforms are seldom the ones who will implement reforms. The latter group of distributed agents is seldom engaged in thinking about reform ideas, however, and is rather an end consumer of decisions that they often disagree with and find difficult to implement. Research shows that reforms often fail because distributed agents (like procurement officers in line ministries, local government tax collectors, and others) are not involved in the reform design process. Those who design reforms in central offices (like procurement bureaus or revenue agencies) in capital cities do not know the political or capacity constraints faced by distributed agents and produce a reform that this latter group cannot (or will not) be comfortable implementing.

Addressing this requires having multi-agent groups involved in reform from the start, and combining in the step-by-step experimentation. Active multi-agency teams of technicians and coalitions of political supporters are needed - not small groups of technocrats in single agencies and singular political champions. Nine different roles must be satisfied when 
thinking of these teams and coalitions, which should be built in Uganda (Andrews 2008, 2010, 2013):

- Authorizers allow the activities to take place; they are often political (in the guiding coalition, supporting the general exercise and checking in every few months) and administrative (facilitating day-to-day work and allowing the technical team members the time to work on the reforms, away from their day-jobs).

- Motivators and inspirational agents keep other agents moving ahead; they can also be in both the political coalitions and administrative teams, such that there is energy behind and within the change process.

- Connectors and conveners help to bring other agents together, in regular meetings and through arm's length collaboration; political connectors and conveners play an important role ensuring that the authorizing coalition always includes the right people, and administrative connectors and conveners ensure that the right technical people are involved (to allow success in the step-by-step reform process).

- Resource providers and funders help to ensure that the teams and coalitions have the capabilities required to fulfil each step in the process; these capabilities include money, information, and time.

- Problem identifiers and communicators help to identify, construct and deconstruct the problems warranting change; they are likely to be both administrative and political, with the former group gathering evidence and packaging the problem (as discussed) and the latter group communicating the problem in a political manner to ensure it receives attention and is used persuasively to facilitate change.

- Ideas people are needed to deconstruct the problem, analyse it, and suggest potential solution pathways; these are mostly administrative people.

- Implementers are those who will have to implement and live with the new rules of the game that emerge from reform processes; they need to be engaged in the process so that they can inform others of the on-the-ground realities that complicate change processes and so that they can open doors for experimentation.

The process of building teams and coalitions that include these kinds of agents is crucial to an effective reform process and to the success of PDIA. It should be done at the start of the process, before any problems are identified and before the process of deconstructing problems and looking for solutions even begins. Furthermore, the team and coalition structures cannot involve just one ministry or organization, as public sector reforms are crosscutting. Also, the team and coalition structures should be dynamic, as reform demands change.

\section{Conclusion}

This paper intends to contribute to the institutional reform discussion that is obviously ongoing in Uganda, and has consistently identified gaps and limits. A recent contributor to this discussion is Guma Prince Karakire (n.d.), who notes that 'Developing countries, Uganda inclusive, have often looked abroad for ideas about how to reform ... However, these processes have often been disastrous. Yet, no one seems to possess a coherent explanation as to why they should fail with such predictable regularity'. The current paper offers an explanation for the failure that has been observed: reforms are being introduced to make 
government look better, based on externally defined best practices. It also offers an empirical way of assessing the gaps and limits produced by such reform approach: metrics and stories are used in all five areas of analysis to show gains, limits and gaps. Finally, it proposes that Uganda can do better with a new reform process.

This paper began by noting that Uganda has been a public sector reform leader in Africa. It has pursued reforms actively and consistently for three decades now, and has produced many laws, processes and structures that are 'best in class' in Africa (and beyond). The problem is that many of the reforms have been limited to these kinds of gains-producing new institutional forms that function poorly and yield limited impacts. Various kinds of data showed-in various areas (civil service and public administration, public financial management, revenue management, procurement, and anti-corruption) - that laws are often not being implemented, processes are being poorly executed, and there is insufficient followup to make sure that new mechanisms work as intended. The paper suggests that government should re-frame its reform agenda to address these limitations and close the gaps between what Uganda's system looks like and how it functions.

The proposed approach to doing reform in the future is called problem-driven iterative adaptation (PDUA) and builds on past reform activity (rather than proposing an entirely new set of solutions). PDIA will require Ugandans to work together and own their reform processes more actively than ever, coming to terms with the problems they face and working iteratively — in broad groups - to find and fit local solutions to these problems. 


\section{Appendix}

Appendix Table 1: Average PEFA scores for different dimension types, 2006, 2009 and 2012

\begin{tabular}{|c|c|c|c|}
\hline Year of PEFA assessment & 2006 & 2009 & 2012 \\
\hline Avg score on de-jure dimensions (quality of laws) & 2.2 & 2.6 & 2.8 \\
\hline Avg PEFA score overall & 2.1 & 2.5 & 2.5 \\
\hline $\begin{array}{l}\text { Avg score on de facto dimensions (quality of actual implementation of } \\
\text { processes) }\end{array}$ & 1.7 & 2 & 2 \\
\hline Year of OBI assessment & & & 2012 \\
\hline $\begin{array}{l}\text { Avg score for upstream OBI transparency (transparency in formulating } \\
\text { budget and communicating spending plans) }\end{array}$ & & & 73 \\
\hline Avg OBI score overall & & & 65 \\
\hline $\begin{array}{l}\text { Avg score for upstream OBI transparency (transparency in executing } \\
\text { budget and communicating spending results) }\end{array}$ & & & 48 \\
\hline
\end{tabular}

Source: Authors' analysis, based on method in Andrews (2011). 
Appendix Table 2: Results from the 2005 and 2007 World Bank and OECD procurement assessments

\begin{tabular}{|c|c|c|c|c|}
\hline \multirow[b]{2}{*}{ I: Legal, regulatory framework } & \multicolumn{3}{|c|}{20052007 Change, \% } & Major achievements \\
\hline & 2.1 & 2.7 & 27 & \\
\hline 1 Legal, regulatory framework & 2.5 & 2.93 & 20 & $\begin{array}{l}\text { Tender documents have been updated but they } \\
\text { still lack updated specifications and other details. }\end{array}$ \\
\hline $\begin{array}{l}2 \text { Implementing regulations, } \\
\text { documentation are provided }\end{array}$ & 1.7 & 2.5 & 50 & $\begin{array}{l}\text { Regulations, tender documents and guidelines } \\
\text { have been created/revised and are more compliant } \\
\text { with internationally accepted practice. }\end{array}$ \\
\hline
\end{tabular}

\section{II: Institutional framework \& management capacity}

\begin{tabular}{|c|c|c|c|c|c|}
\hline & & 1.4 & 1.9 & 35 & \\
\hline 3 & $\begin{array}{l}\text { Integration, mainstreaming of system } \\
\text { in governance framework }\end{array}$ & 1.5 & 1.5 & 0 & No improvement \\
\hline 4 & $\begin{array}{l}\text { Normative, regulatory functions } \\
\text { assigned }\end{array}$ & 2.5 & 2.75 & 10 & $\begin{array}{l}\text { PPRA is staffed appropriately but lacks other } \\
\text { resources to function effectively. }\end{array}$ \\
\hline 5 & Institutional development capacity & 0.25 & 1.5 & 500 & $\begin{array}{l}\text { New website exists and a journal is being } \\
\text { introduced but both are still not fully functional. } \\
\text { New IT system has been piloted and is due to be } \\
\text { rolled out but is still not functional. Training is } \\
\text { being provided but there are no assessments of } \\
\text { impact. }\end{array}$ \\
\hline
\end{tabular}

\section{III: Procurement operations and market practices}

$1.3 \quad 1.4$

6 Efficiency of procurement operations in practice

7 Functionality of public procurement market

8 Existence of contract administration, dispute resolution mechanisms $\begin{array}{llll}1.5 & 1.5 & 0 & \text { No improvement }\end{array}$

$\begin{array}{lll}1.5 & 1.25 & -17\end{array}$ There are insufficient private operators for many goods and services.

$1 \quad 1.5 \quad 50$ New regulations and tendering documents have been introduced.

\section{IV: System integrity and transparency}

I

9 Effectiveness of control and audit system

10 Efficiency of appeals mechanism

11 Accessibility to information

12 Ethics and anticorruption policy and measures

\section{$\begin{array}{lll}1.3 & 1.8 & 38\end{array}$}

$0.81 .6100 \quad$ Audit reports produced but implementation of recommendations is 'limited', remains a problem. Manuals define audit process but many audits not properly submitted; responses to audits weak.

$\begin{array}{llll}1.4 & 2.2 & 57 & \text { New website established; most bids announced; }\end{array}$ authority independent in part but does not have own budget and is supervised by the Ministry of Finance.

220 No improvement

$\begin{array}{llll}1.6 & 2 & 27 & \text { New laws require anti-bribery declaration and }\end{array}$ investigation of corruption; $4 \%$ of cases have been put forward to prosecution; shows legal mechanisms exist but 'are poorly enforced'; Officials subject to formal Code of Ethics but verification is 'weak'.

Source: World Bank (2004); OECD (2007). 
Appendix Table 3: Global Integrity assessments of Uganda's public procurement system

\begin{tabular}{|c|c|c|c|}
\hline \multirow{2}{*}{\multicolumn{2}{|c|}{ Area evaluated }} & 2007 & 2011 \\
\hline & & \multicolumn{2}{|c|}{ Score (out of 100) } \\
\hline 48 & Is the public procurement process effective? & 88 & 90 \\
\hline$-a$ & In law, regulations address conflicts of interest for public procurement officials. & 100 & 100 \\
\hline$-b$ & In law, there is mandatory professional training for public procurement officials. & 100 & 100 \\
\hline$-c$ & In practice, conflicts of interest regulations ... are enforced. & 50 & 50 \\
\hline$-d$ & In law, a mechanism monitors assets, incomes spending habits of ... officials. & 100 & 100 \\
\hline$-e$ & In law, major procurements require competitive bidding. & 100 & 100 \\
\hline$-f$ & In law, strict formal requirements limit the extent of sole sourcing. & 100 & 100 \\
\hline$-f$ & In law, unsuccessful bidders can instigate an official review of ... decisions. & 100 & 100 \\
\hline$-\mathrm{h}$ & In law, unsuccessful bidders can challenge procurement decisions in a court of law. & 100 & 100 \\
\hline$-\mathrm{i}$ & $\begin{array}{l}\text { In law, companies guilty of major violations of procurement regulations (i.e. bribery) } \\
\text { are prohibited from participating in future procurement bids. }\end{array}$ & 100 & 100 \\
\hline$-j$ & $\begin{array}{l}\text { In practice, companies guilty of major violations of procurement regulations (i.e. } \\
\text { bribery) are prohibited from participating in future procurement bids. }\end{array}$ & 25 & 50 \\
\hline 49 & Can citizens access the public procurement process? & 70 & 79 \\
\hline$-a$ & In law, citizens can access public procurement regulations. & 100 & 100 \\
\hline$-b$ & In law, government is required to publicly announce results of... decisions. & 100 & 100 \\
\hline$-\mathrm{c}$ & In practice, citizens can access procurement regulations within a reasonable period. & 50 & 75 \\
\hline$-d$ & In practice, citizens can access public procurement regulations at a reasonable cost. & 50 & 75 \\
\hline$-e$ & In practice, major public procurements are effectively advertised. & 50 & 75 \\
\hline$-f$ & In practice, citizens can access the results of major public procurement bids. & 75 & 50 \\
\hline
\end{tabular}

Source: Global Integrity (2007) and (2011).

Appendix Table 4: Comparison of global integrity assessments of anti-corruption mechanisms

\begin{tabular}{|c|c|c|c|c|c|c|}
\hline & & Uganda & Kenya & Ghana & Sierra Leone & United States \\
\hline Overall global integrity score & & 72 & 68 & 67 & 64 & 85 \\
\hline Legal framework & & 98 & 84 & 79 & 78 & 90 \\
\hline $\begin{array}{l}\text { Full compliance with questions about } \\
\text { laws, }\end{array}$ & $\%$ & 95 & 81 & 76 & 76 & 90 \\
\hline Actual Implementation & & 51 & 53 & 54 & 52 & 79 \\
\hline $\begin{array}{l}\text { Full compliance with questions about } \\
\text { practice and implementation, }\end{array}$ & $\%$ & 11 & 19 & 19 & 30 & 49 \\
\hline Implementation gap & & 47 & 30 & 25 & 25 & 12 \\
\hline
\end{tabular}

Source: Authors' analysis 


\section{References}

AfDB (African Development Bank) (2010). 'Domestic Resource Mobilization for Poverty Reduction in East Africa: Uganda Case Study'. Regional Development East A (OREA) Paper. November. Available at: www.afdb.org/fileadmin/uploads/afdb/Documents /Project-and-Operations/Uganda $\% 20$ case $\% 20$ study $\% 20$ final.pdf

Agaba, E., and N. Shipman. (2007). 'Public Procurement Reform in Developing Countries: The Ugandan Experience'. In G. Pika and K. V. Thai (eds). Advancing Public Procurement: Practices, Innovation and Knowledge-Sharing Boca Raton, FL: PrAcademics Press, 373-91.

Andrews, M. (2003a). 'Assessing Local Government Performance in Developing Countries'. In A. Shah (ed.), Measuring Government Performance in the Delivery of Public Services. Washington, DC: World Bank.

Andrews, M. (2003b). 'New Public Management and Democratic Participation: Complementary or Competing Reforms? A South African Study'. International Journal of Public Administration, 26(8-9): 991-1015.

Andrews, M. (2005). 'Performance-Based Budgeting Reform'. In A. Shah (ed.), Fiscal Management, Public Sector Governance and Accountability Series. Washington, DC: World Bank.

Andrews, M. (2008). 'Creating Space for Effective Political Engagement in Development'. Harvard Kennedy School Working Paper RWP08-15. Cambridge, MA: Harvard University.

Andrews, M. (2011). 'Which Organizational Attributes are Amenable to External Reform? An Empirical Study of African Public Financial Management'. International Public Management Journal, 14(2): 131-56.

Andrews, M. (2012a). 'Will Black Economic Empowerment Catalyse South African Growth?'. International Journal of Entrepreneurship and Small Business, 17(1): 57-117.

Andrews, M. (2012b). 'The Logical Limits OF Best Practice Administrative Solutions in Developing Countries'. Public Administration and Development, 32(2): 137-53.

Andrews, M. (2013). The Limits of Institutional Reform in Development. New York, NY: Cambridge University Press.

Andrews, M., and H. Hill (2003). 'The Impact of Traditional Budgeting Systems on the Effectiveness of Performance-Based Budgeting: A Different Viewpoint on recent Findings'. International Journal or Public Administration, 26(2): 135-55.

Andrews, M., and L. Schroeder (2003). 'Sectoral Decentralization and Intergovernmental Arrangements in Africa'. Public Administration and Development, 23(1): 29-40.

Andrews, M., J. McConnell, and A. Wescott (2008). 'Development as Leadership Led Growth'. Washington, DC: World Bank.

Andrews, M., L. Pritchett, and M. Woolcock (2012). 'Escaping Capability Traps through Problem-Driven Iterative Adaptation'. Harvard Kennedy School Faculty Research Working Paper Series RWP12-036. Cambridge, MA: Harvard University.

Bashaasha, B., M. N. Mangheni, and E. Nkonya (2011). 'Decentralization and Rural Service Delivery in Uganda'. IFPRI Discussion Paper 01063. Washington, DC: International Food Policy Research Institute. 
Basheka, B. C. (2008). 'Procurement Planning and Accountability of Local Government Procurement Systems in Developing Countries: Evidence from Uganda Journal of Public Procurement, 8(3): 379-406.

Bategeka, L. N. (2013). 'The Role of the State in Economic Development: Employment Challenges in Uganda'. EPRC Working Paper. Kampala: Economic Policy Research Centre.

Business Daily (2013). 'Uganda Beats Kenya in Budget Openness Score'. 12 February.

Drummond, P., W. Daal, N. Srivistava, and L. E. Oliveira (2012). 'Mobilizing Revenue in Sub-Saharan Africa: Empirical Norms and Key Determinants'. IMF Working Paper WP/12/108. Washington, DC: IMF.

Fjeldstad, O.-H. (2005). 'Corruption in Tax Administration: Lessons from Institutional Reforms in Uganda'. CMI Working Paper. Bergen: Chr. Michelsen Institute.

Flanary, R., and D. Watt (1999). 'The State of Corruption: A Case Study of Uganda'. Third World Quarterly, 20(3): 515.

Global Integreity (2007). 'Global Integrity Assessment'. Available at: www.report.global integrity.org/Uganda/2007/scorecard/64.

Global Integreity (2011). 'Global Integrity Assessment'. Available at: www.global integrity.org/report/Uganda/2011/scorecard.

Independent, The (2010). 'Uganda's Most Corrupt'. 2 August.

International Tax Dialogue (2010). 'Revenue Administration in Sub-Saharan Africa'. ITD Comparative Information Series, No.1. Available at www.itdweb.org

ISS (Innovations for Successful Societies) (2008). Page 8 of the interview transcript for Princeton University's Innovations for Successful Societies programme [conducted by Andrew Schakwyk on 1 December 2008]. Princeton, NJ. Available from www.princeton.edu/successfulsocieties

Ittner, S. (2009). 'Fighting Corruption in Africa-A Comparative Study of Uganda and Botswana'. PhD Dissertation. Speyer: Speyer University.

Karakire, G. P. (n.d.). 'Three Decades of Orthodox Approaches to Administrative Reform in Africa: the Ugandan Experience'. Working Paper. Kampala: African Center for Management and Leadership. Available at www//ssrn.com/abstract=2097123.

Kidd, M., and W. Crandall (2006). 'Revenue Authorities: Issues and Problems in Evaluating their Success'. IMF Working Paper 06/240. Washington, DC: IMF.

Kyarimpa, G. E. (2009). 'Comparative Administrative Reform: The Rhetoric and Reality of the Civil Service Reform Programmes in Uganda and Tanzania'. FIU Electronic Theses and Dissertations, Paper 196. Miami, FL: Florida International University.

Langseth, P., and D. Pezzullo (2000). 'Country Assessment, Corruption in Uganda-Analysis and Suggestions for Next Steps'. Oslo: Norwegian Agency for Development Cooperation (NORAD). Available at: www.norad.no/default.asp?V_DOC_ID $=672$

Mulondo, E. (2013). 'Uganda Reforms 'not Good Enough'. East African, 11 May.

New Vision (2012). PPDA Supplement 33. Wednesday 19 September. 
OECD (2007). 'Assessment of the Country's Procurement System'. Available at: www.oecd.org/development/effectiveness/40778063.pdf

Olum, Y. (2003). 'Public Service Reform in Uganda (1998-2002): A Critical Appraisal'. AAPAM Paper. Available at: www.unpan1.un.org/intradoc/groups/public/ documents/AAPAM/UNPAN025827.pdf

Otindo, O. (2012). 'Major Problems Facing Uganda Today'. AfricaW. 9 February. Online

Republic of Uganda (2012). 'Government Annual Performance Report, FY2011/12', Vol 1. November. Kampala: Office of the Prime Minister.

Robinson, M. (2006). 'The Political Economy of Governance Reforms in Uganda'. IDS Discussion Paper 3. Brighton: Institute of Development Studies.

Mwenda, A. (2011). 'Uganda Has 3rd Largest Cabinet in the World'. The Independent, 19 January.

Ronald, A. (2011). 'Tax Reforms and Domestic Revenue Mobilization in Uganda Revenue Authority: A Case Study of Uganda Revenue Authority Entebbe'. Research Report for Bachelor of Commerce Degree. Makerere University.

Therkilden, O. (2004). 'Autonomous Tax Administration in Sub-Saharan Africa: The Case of the Uganda Revenue Authority'. Journal of Modern African Studies, 31(1): 59-88.

Therkildsen, O., and P. Tidemand (2007). 'Staff Management and Organizational Performance in Tanzania and Uganda: Public Servant Perspectives'. Final Report for Danish Institute for International Studies. Copenhagen.

UBOS (Uganda Bureau of Statistics) (2012). 'Key Economic Indicators' 86th Issue. Kampala: Uganda Bureau of Statistics. Available at: www.ubos.org

Williamson, T. (2003). 'Targets and Results in Public Sector Management: Uganda Case Study’. ODI Working Paper 205. London: Overseas Development Institute.

World Bank (2004). 'Uganda Country Procurement Assessment Report'. Washington, DC: World Bank. Available at: www-wds.worldbank.org/external/default/ WDSContent Server/WDSP/IB/2005/06/03/000011823_20050603171251/Rendered/PDF/324990v10U G0CP1ve0Summary01public10.pdf. 